
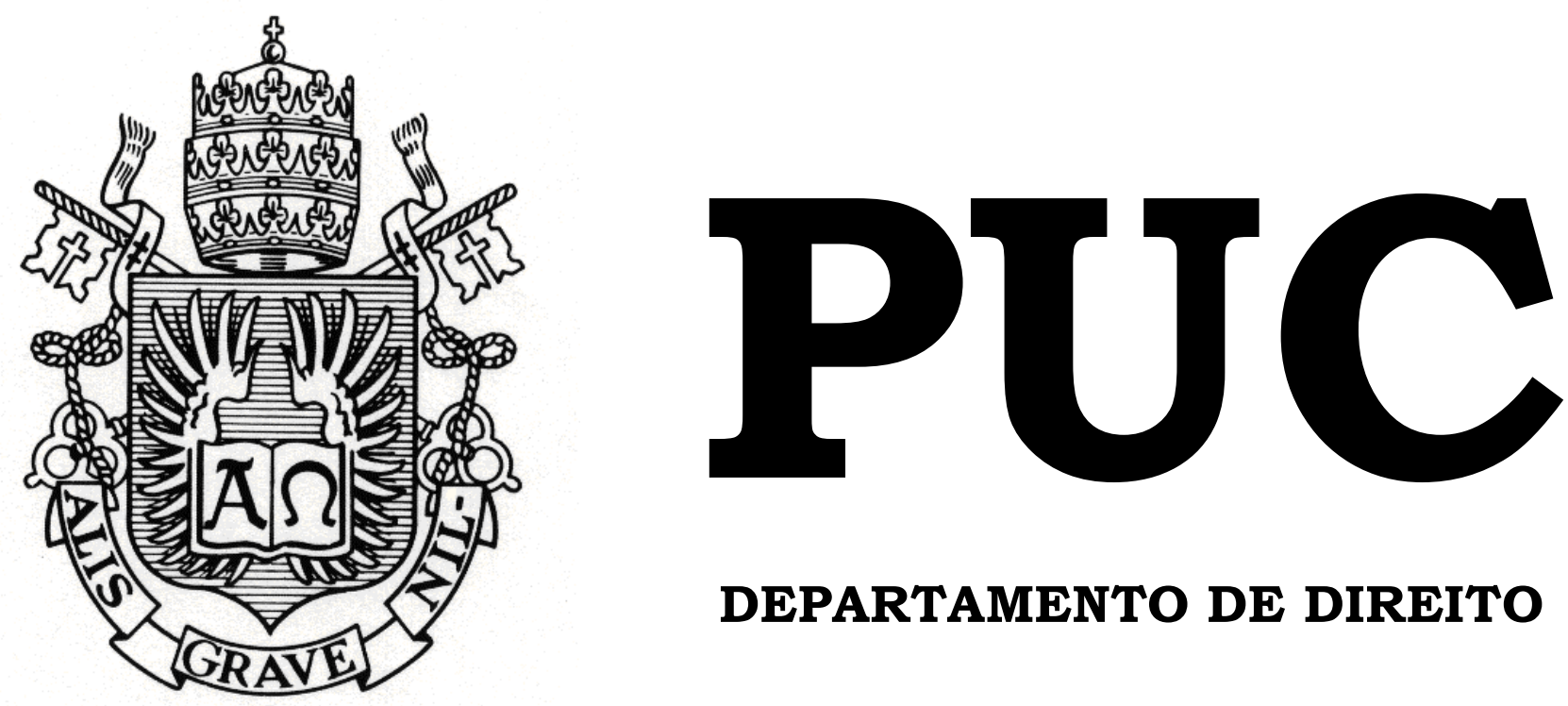

DEPARTAMENTO DE DIREITO

A Responsabilidade Civil por Dano Concorrencial como Incentivo à Celebração de Acordo de Leniência

por

Pedro Pedrosa de Andrade Figueira

ORIENTADOR: Professor Marcelo Fernandez Trindade

2019.1

PONTIFÍCIA UNIVERSIDADE CATÓLICA DO RIO DE JANEIRO

RUA MARQUÊS DE SÃO VICENTE, 225 - CEP 22453-900

RIO DE JANEIRO - BRASIL 


\title{
A Responsabilidade Civil por Dano Concorrencial como Incentivo à Celebração de Acordo de Leniência
}

\author{
por
}

Pedro Pedrosa de Andrade Figueira

Monografia apresentada ao

Departamento de Direito da Pontifícia Universidade Católica do Rio de Janeiro (PUC-Rio) para a obtenção do Título de Bacharel em Direito.

Orientador: Professor Marcelo Fernandez Trindade 


\section{Resumo:}

O presente trabalho busca estudar a responsabilidade civil concorrencial da empresa que celebra acordo de leniência no âmbito do CADE e as consequências de sua responsabilização pelos danos causados, bem como analisar novas possibilidades ao legislador de modo que seja garantido o ressarcimento do dano causado pela infração concorrencial e preservada a atratividade do programa de leniência brasileiro.

\section{Palavras Chave:}

Responsabilidade civil. Dano concorrencial. Acordo de leniência. Direito comparado. Indenização. Prescrição. Legitimidade. Solidariedade. Prova. 


\section{Sumário}

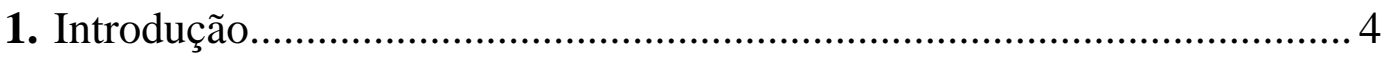

2. Dano Concorrencial e Acordo de Leniência ............................................. 9

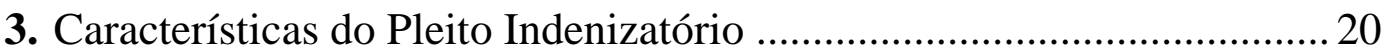

3.1. Responsabilidade Civil Concorrencial ........................................... 20

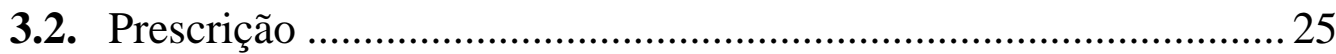

3.3. Legitimidade Ativa e Passiva ....................................................... 28

3.4. Solidariedade no crime concorrencial ................................................. 30

3.5. Prova decorrente de acordo de leniência........................................... 31

4. As Experiências nos EUA e na União Europeia ............................................ 36

4.1. EUA: "Antitrust Criminal Penalty Enhancement and Reform Act" -

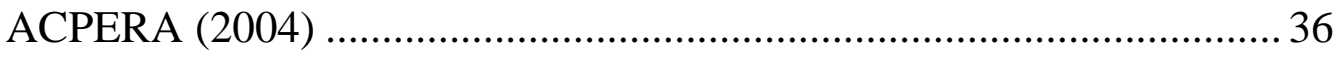

4.2. Europa: "Diretiva sobre Ações de Ressarcimento de Danos Concorrenciais na União Europeia" (2014) .............................................. 40

5. Previsão de Nova Regulação no Brasil: O Projeto de Lei nº 11.275/2018 e uma Sugestão aos Legisladores............................................................. 46

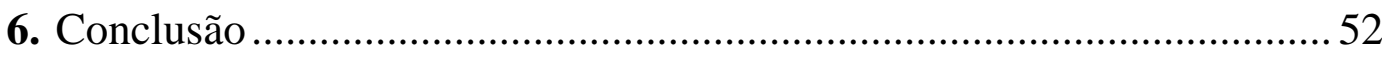




\section{Introdução}

Questão legal interessante, que ainda não foi solucionada pelo ordenamento jurídico brasileiro, versa sobre a possibilidade de responsabilização civil decorrente de dano concorrencial, ou seja, do particular lesado por uma conduta considerada anticoncorrencial exigir a reparação pelos danos que sofreu decorrentes da conduta ilícita. Ainda de modo mais específico, o presente trabalho visa a expor tais questões, em especial quando o dano concorrencial é deflagrado pela proposta e celebração de acordo de leniência entre o Conselho Administrativo de Defesa Econômica-CADE e o infrator.

O meu interesse sobre o tema resultou do estudo de um caso específico. Em julho de 2013 a empresa Siemens Ltda. celebrou acordo de leniência com o CADE, denunciando a existência de cartel com o objetivo de fraudar licitações no setor metroferroviário do Estado de São Paulo. Nos termos do acordo, a Siemens informou ao CADE a existência do cartel e forneceu à autarquia documentos para sua comprovação, em troca de imunidade total no procedimento administrativo ${ }^{1}$, nos termos do art. $86 \mathrm{da}$ Lei n ${ }^{\circ} 12.529 / 11^{2}$ ("Lei de Concorrência").

Com fundamento nesse acordo, em agosto de 2013 o Ministério Público de São Paulo ajuizou Ação Civil Pública contra catorze réus, requerendo a indenização de $\mathrm{R} \$ 2,5$ bilhões aos cofres públicos. Na ação, o Ministério Público identifica cinco contratos que considera fraudados, entre acordos de manutenção de trens e construção de linhas novas.

Ou seja, conquanto tenha celebrado acordo que the garanta imunidade perante a autarquia, a Siemens pode ser responsabilizada - de forma solidária -, pelo pagamento do total de $\mathrm{R} \$ 2,5$ bilhões na ação acima mencionada.

1 https://www.valor.com.br/politica/3223282/relatorio-do-cade-descreve-acordos-para-cartel-emmetros-de-sp-e-df e https://g1.globo.com/economia/noticia/2018/12/12/cade-pede-condenacao-de16-empresas-por-cartel-de-trens-e-metros.ghtml, ambos acessados em 24/01/2019 às 14h30.

2 "Art. 86. O Cade, por intermédio da Superintendência-Geral, poderá celebrar acordo de leniência, com a extinção da ação punitiva da administração pública ou a redução de 1 (um) a 2/3 (dois terços) da penalidade aplicável, nos termos deste artigo (...)" 
Ressalta-se que correm, nos Tribunais de São Paulo e do Distrito Federal, diversas outras ações fundadas no referido acordo, derivadas de outros contratos públicos, nas quais a empresa também compõe o polo passivo.

No caso exposto, apenas o Ministério Público ajuizou ação buscando reparação pelas fraudes. No entanto, não é difícil imaginar situação em que empresa que não tenha participado no cartel se sinta prejudicada pela possível perda do contrato com a Administração Pública e demande reparação pelos lucros que poderia ter na execução deste contrato, que efetivamente foram os lucros da empresa fraudadora.

O mesmo ocorre para danos concorrenciais na esfera privada. Exemplifica-se que, após deflagrada a existência de cartel que controlou o mercado de determinado produto por anos, seus consumidores exijam a reparação integral do dano pelos valores elevados pagos por aquele produto devido à precificação abusiva.

Destaca-se, neste ponto, que o art. 47 da Lei de Concorrência ${ }^{3}$ assegura o direito de todos os lesados pelo dano concorrencial buscarem indenização por perdas e danos em juízo, seja em defesa de direitos individuais ou individuais homogêneos.

O número de ações judiciais que pleiteiam indenização por tais danos no Brasil, ainda que módico, tende a crescer exponencialmente. As principais ações deste tipo, ainda, são ajuizadas pelo Ministério Público buscando a indenização aos cofres públicos, como visto no exemplo acima. No entanto, ao passo que novos danos lesivos à sociedade forem sendo investigados e comprovados pelo CADE, crescerá a movimentação de lesados para serem ressarcidos, em ações muitas vezes milionárias.

Como exemplo da quantidade de recursos que tais ações podem movimentar, entre 1990 e 2007 nos Estados Unidos, estima-se que USD 19.7 bilhões foram pagos em indenizações decorrentes de danos patrimoniais

\footnotetext{
3 “Art. 47. Os prejudicados, por si ou pelos legitimados referidos no art. 82 da Lei no 8.078 , de 11 de setembro de 1990, poderão ingressar em juízo para, em defesa de seus interesses individuais ou individuais homogêneos, obter a cessação de práticas que constituam infração da ordem econômica, bem como o recebimento de indenização por perdas e danos sofridos, independentemente do inquérito ou processo administrativo, que não será suspenso em virtude do ajuizamento de ação".
} 
causados por cartéis internacionais ${ }^{4}$. Ainda assim, trata-se de tema pouco estudado no direito brasileiro.

Aqui, o conflito a ser ponderado é que tal reparação, integral e solidária, desincentiva a celebração de acordos de leniência, uma das principais ferramentas do CADE para a descoberta de condutas concorrenciais lesivas à sociedade . Como visto, embora a Siemens tenha dado notícia do funcionamento de cartel bilionário em setor de relevante interesse público e contribuído com as investigações para a sua dissolução, ainda possui o risco de ser responsabilizada pelo pagamento integral de mais de $\mathrm{R} \$ 2.5$ bilhões. Diante disso, a consequência óbvia é que a possibilidade de indenização a terceiros reduz gravemente os incentivos à cooperação das empresas.

Apesar disso, a obrigação de reparar os danos causados pela infração concorrencial é importante medida para que tais infrações sequer existam. Nas palavras do Conselheiro Fernando de Magalhães Furlan, do CADE:

\begin{abstract}
"Como argumentado anteriormente neste voto, a sanção imposta pelo CADE dedica-se essencialmente a abordar o dano causado à concorrência como instrumento orientador da atividade econômica no Brasil. A multa imposta pelo Conselho não repara os danos patrimoniais e morais causados a pessoas específicas. A indenização por tais danos deve ser engendrada pelas vias judiciais cabíveis.

A via de maior destaque é a ação civil pública. Nos termos do art. $1^{\circ}$, inciso $\mathrm{V}$, da Lei $\mathrm{n}^{\circ} 7.347 / 85$, cabe ação civil pública em face de "infração da ordem econômica e da economia popular'. Esta ação constitui um elemento essencial para a política geral de defesa da concorrência. Por este motivo, voto pelo encaminhamento desta decisão ao ilustre representante do MPF junto ao CADE para, julgando pertinente, estruturar a ação do Ministério Público nesta seara.

Merece destaque ainda a ação privada, ajuizada pela vítima do cartel em busca de reparação pelos danos causados. A utilidade de ações privadas para a promoção da concorrência já foi comprovada em jurisdições estrangeiras. Nos Estados Unidos, onde a lei estabelece que os prejudicados por um cartel têm direito a um valor equivalente a três vezes a indenização ordinariamente cabível, a litigância privada
\end{abstract}

\footnotetext{
4 "Information on settlement amounts is available for a large majority of the cartels, but several are still being negotiated. In the United States, private parties recovered at least $\$ 19.7$ billion from defendants in international cartels" (Connor, John. 2008. Global Antitrust Prosecutions of International Cartels: Focus on Asia. SSRN Electronic Journal).

${ }^{5}$ De 2003 a 2017, foram celebrados 82 acordos de leniência no âmbito do CADE, sendo 21 celebrados apenas no último ano $(25,6 \%)$. Fonte: http://www.cade.gov.br/assuntos/programa-deleniencia, acesso em 23/01/2019, às 19h45.

${ }^{6}$ Voto do Conselheiro Relator Fernando de Magalhães Furlan no processo administrativo do CADE $\mathrm{n}^{\mathrm{o}}$ 08012.009888/2003-70, julgado em 01/09/2010, p. 126.
} 
já se transformou em peça chave da política de defesa da concorrência no país. Trata-se de mais um desestímulo à infração da lei.

No Brasil, porém, quase não se tem notícia de ações privadas em razão de danos causados por cartéis. Perde-se, assim, um importante fator a desestimular a prática de conluio. E os prejudicados também deixam de ser ressarcidos pelos danos causados".

O presente trabalho se propõe a estudar este tema, com o objetivo de analisar soluções e propor ideias que garantam, por um lado, o direito à reparação integral do dano daqueles lesados pelo ato ilícito e as barreiras para a prática de crimes concorrenciais e, por outro, o incentivo à celebração de acordos de leniência.

O escopo do presente trabalho é tanto o direito civil quanto concorrencial. No âmbito do primeiro, analisaremos a configuração e as características da responsabilidade civil das empresas que cometem infrações concorrenciais, bem como a análise processual da prova produzida no âmbito do processo administrativo para celebração do acordo de leniência no CADE e sua instrução no procedimento judicial de responsabilidade civil. No campo do direito concorrencial, o trabalho se limitará ao estudo do dano concorrencial em geral e da celebração de acordo de leniência por empresas que cometem infrações concorrenciais.

No intuito de alcançar seu objetivo, na primeira parte do trabalho será feita exposição sobre o conceito de dano concorrencial e da reparação civil que ele enseja, além do desincentivo que tal reparação provoca à confissão das empresas que o desejam fazer.

No segundo capítulo, se estudarão as características do pleito indenizatório, tais como a responsabilidade civil decorrente do ato ilícito concorrencial e a produção de provas no procedimento, tendo em vista o imprescindível sigilo que cerca a celebração de acordo de leniência e a necessidade de provar-se o ato ilícito e os danos causados para que ocorra a reparação.

Em seguida, serão analisados os tratamentos dados aos problemas que se apresentam tanto nos Estados Unidos, por meio do "Antitrust Criminal 
Enhancement and Reform Act", quanto na Europa, por meio da "Diretiva sobre Ações de Ressarcimento de Danos Concorrenciais da União Europeia". Por fim, serão analisadas as propostas em curso no Brasil, como o Projeto de Lei $n^{\circ}$ 283/2016, atualmente tramitando na Câmara dos Deputados, e outras possibilidades ao legislador. 


\title{
2. Dano Concorrencial e Acordo de Leniência
}

\author{
Em primeiro lugar, deve-se delimitar os danos que ensejam a \\ reparação civil estudada, quais sejam, os danos decorrentes de ilícitos \\ concorrenciais. Para tanto, recorre-se ao art. 36 da Lei de Concorrência ${ }^{7}$, que
} lista as infrações à ordem econômica. Confira-se: ${ }^{7}$ O parágrafo terceiro do referido artigo lista, ainda, exemplos de condutas que se encaixem nestas
situações: " $\$ 3^{\circ}$ As seguintes condutas, além de outras, na medida em que configurem hipótese
prevista no caput deste artigo e seus incisos, caracterizam infração da ordem econômica:
I - acordar, combinar, manipular ou ajustar com concorrente, sob qualquer forma:

a) os preços de bens ou serviços ofertados individualmente;

b) a produção ou a comercialização de uma quantidade restrita ou limitada de bens ou a prestação de um número, volume ou frequência restrita ou limitada de serviços;

c) a divisão de partes ou segmentos de um mercado atual ou potencial de bens ou serviços, mediante, dentre outros, a distribuição de clientes, fornecedores, regiões ou períodos;

d) preços, condições, vantagens ou abstenção em licitação pública;

II - promover, obter ou influenciar a adoção de conduta comercial uniforme ou concertada entre concorrentes;

III - limitar ou impedir o acesso de novas empresas ao mercado;

IV - criar dificuldades à constituição, ao funcionamento ou ao desenvolvimento de empresa concorrente ou de fornecedor, adquirente ou financiador de bens ou serviços;

$\mathrm{V}$ - impedir o acesso de concorrente às fontes de insumo, matérias-primas, equipamentos ou tecnologia, bem como aos canais de distribuição;

VI - exigir ou conceder exclusividade para divulgação de publicidade nos meios de comunicação de massa;

VII - utilizar meios enganosos para provocar a oscilação de preços de terceiros;

VIII - regular mercados de bens ou serviços, estabelecendo acordos para limitar ou controlar a pesquisa e o desenvolvimento tecnológico, a produção de bens ou prestação de serviços, ou para dificultar investimentos destinados à produção de bens ou serviços ou à sua distribuição;

IX - impor, no comércio de bens ou serviços, a distribuidores, varejistas e representantes preços de revenda, descontos, condições de pagamento, quantidades mínimas ou máximas, margem de lucro ou quaisquer outras condições de comercialização relativos a negócios destes com terceiros;

$\mathrm{X}$ - discriminar adquirentes ou fornecedores de bens ou serviços por meio da fixação diferenciada de preços, ou de condições operacionais de venda ou prestação de serviços;

XI - recusar a venda de bens ou a prestação de serviços, dentro das condições de pagamento normais aos usos e costumes comerciais;

XII - dificultar ou romper a continuidade ou desenvolvimento de relações comerciais de prazo indeterminado em razão de recusa da outra parte em submeter-se a cláusulas e condições comerciais injustificáveis ou anticoncorrenciais;

XIII - destruir, inutilizar ou açambarcar matérias-primas, produtos intermediários ou acabados, assim como destruir, inutilizar ou dificultar a operação de equipamentos destinados a produzi-los, distribuí-los ou transportá-los;

XIV - açambarcar ou impedir a exploração de direitos de propriedade industrial ou intelectual ou de tecnologia;

$\mathrm{XV}$ - vender mercadoria ou prestar serviços injustificadamente abaixo do preço de custo;

$\mathrm{XVI}$ - reter bens de produção ou de consumo, exceto para garantir a cobertura dos custos de produção;

XVII - cessar parcial ou totalmente as atividades da empresa sem justa causa comprovada;

XVIII - subordinar a venda de um bem à aquisição de outro ou à utilização de um serviço, ou subordinar a prestação de um serviço à utilização de outro ou à aquisição de um bem; e

XIX - exercer ou explorar abusivamente direitos de propriedade industrial, intelectual, tecnologia ou marca". 
Art. 36. Constituem infração da ordem econômica, independentemente de culpa, os atos sob qualquer forma manifestados, que tenham por objeto ou possam produzir os seguintes efeitos, ainda que não sejam alcançados:

I - limitar, falsear ou de qualquer forma prejudicar a livre concorrência ou a livre iniciativa;

II - dominar mercado relevante de bens ou serviços;

III - aumentar arbitrariamente os lucros; e

IV - exercer de forma abusiva posição dominante.

Assim, o presente estudo versará somente sobre os danos que são consequência de condutas anticoncorrenciais, atos ilícitos nos termos do art. 36 da Lei de Concorrência.

O grande problema enfrentado pelos entes responsáveis pelo combate a condutas anti-concorrenciais é a descoberta dos atos ilícitos. Ainda que, por força do art. 13 da Lei de Concorrência ${ }^{8}$, o CADE possa requerer ao poder judiciário a concessão de diversas medidas judiciais com o objetivo único de instruir eventual processo administrativo, dificilmente os atores econômicos que visam a cometer crime concorrencial arquivam documentos, mensagens, atas de reuniões, planilhas que comprovem sua atuação abusiva ou sua estratégia, devido ao caráter clandestino e ilegal da prática. Além disto, é preciso haver indícios de crimes. Sem provas robustas, impossível caracterizar e demonstrar eventuais condutas ilícitas de empresas, mesmo que tal atuação garanta aos agentes econômicos lucros supracompetitivos.

Diante da dificuldade de obtenção de provas, o programa de leniência se apresenta como incentivo às empresas a denunciarem eventuais atividades ilícitas nas quais participaram, em troca de vantagens atribuídas por lei, como a imunidade de penas administrativas e criminais ${ }^{9}$, em casos de prática de

\footnotetext{
8 “Art. 13. Compete à Superintendência-Geral: (...)

VI - no interesse da instrução dos tipos processuais referidos nesta Lei: (...)

d) requerer ao Poder Judiciário, por meio da Procuradoria Federal junto ao Cade, mandado de busca e apreensão de objetos, papéis de qualquer natureza, assim como de livros comerciais, computadores e arquivos magnéticos de empresa ou pessoa física, no interesse de inquérito administrativo ou de processo administrativo para imposição de sanções administrativas por infrações à ordem econômica, aplicando-se, no que couber, o disposto no art. 839 e seguintes da Lei no 5.869 , de 11 de janeiro de 1973 - Código de Processo Civil, sendo inexigível a propositura de ação principal”.

${ }^{9}$ Cumpre ressaltar, nesse ponto, que o programa de leniência brasileiro permite a celebração do acordo de leniência apenas pela primeira empresa denunciante. Objetiva-se, assim, a criação de uma "corrida" entre as empresas participantes do cartel para que todas busquem ser a primeira a denunciálo.
} 
carteis. Neste ponto, importante destacar trecho de estudo do Ministério

Público Federal acerca do instituto ${ }^{10}$ :

\begin{abstract}
"O sentido e o alcance da leniência, contudo, não se esgotam tão somente em oferta de benefícios à pessoa jurídica que, após corromper, coopera. Trata-se, em sua essência, de instituto de corte dúplice. De um lado, consiste em técnica especial de investigação, que visa permitir que o Estado se valha da colaboração ativa, livre e voluntária de infrator, que, antes de deflagrada uma investigação ou, embora iniciada, mas durante seu curso, traga relevantes e inéditas informações sobre práticas delitivas, sua autoria e materialidade, além da indicação de meios probatórios. Justifica-se francamente na constatação pragmática e simples de que, muitas vezes, o desbaratamento de delitos organizacionais é tarefa complexa, que envolve a custosa e improvável identificação de atuação ilícita coordenada e organizada, com liame de confiança e sigilo entre os perpetradores. Ou seja, o instrumento de consensualidade encerrado no acordo de leniência é algo mais que uma simples confissão, já que exige entrega, sem reserva mental, de dados mais amplos e sensíveis sobre condutas de terceiros, além da própria, bem como indicação e fornecimento de provas e de caminhos probatórios, e, por isto mesmo, pode ensejar significativas mitigações das penas ou, em casos isolados, sua remissão total.

Deriva disto que, em configuração bifronte, apresenta-se, de outro lado, também como um meio de defesa, uma estratégia à disposição do infrator na avaliação das probabilidades relacionadas a sua efetiva punição ou às possibilidades concretas de esquivar-se dela. Mas, ainda assim e por isto mesmo, uma vez inserido na ordem jurídica, trata-se de instrumento oferecido à defesa, cujo manejo não pode ser obstado ou dificultado injustamente, devendo, ao revés, ser autenticamente permitido ao agente colaborador a ele recorrer, e, através de juízo de proporcionalidade, que leve em conta a cooperação com o Estado no curso de investigações e para o maior proveito em relação às sanções que lhe podem ser impostas, dele beneficiar-se em várias vertentes, considerando-se especialmente sua sujeição ao sistema de múltipla incidência de responsabilização do ordenamento vigente".
\end{abstract}

Assim, o acordo de leniência se apresenta como ferramenta essencial para a descoberta de crimes concorrenciais, tanto em âmbito nacional quanto mundial.

Inicialmente, o programa de leniência foi introduzido no ordenamento jurídico brasileiro pela Lei $\mathrm{n}^{\circ} 10.149 / 00$. O procedimento para a celebração do acordo foi regulamentado por meio da Portaria do Ministério da Justiça $n^{\circ}$ 456/2010, que dispôs sobre todos os procedimentos administrativos expostos na antiga Lei de Defesa da Concorrência (Lei n $\left.{ }^{\circ} 8.884 / 94\right)$, para apuração,

\footnotetext{
${ }^{10}$ Estudo Técnico n ${ }^{\circ}$ 01/2017. $5^{\text {a }}$ Câmara de Coordenação e Revisão do Ministério Público Federal - Combate à Corrupção. Disponível em https://bit.ly/2JxMQdG. Consultado em 22.03.19, às 18h55.
} 
prevenção ou repressão de infrações contra a ordem econômica no âmbito da Secretaria de Direito Econômico ${ }^{11}$.

Atualmente, na vigência da Lei $\mathrm{n}^{\circ} 12.529 / 11$, para que a pessoa leniente possa se habilitar ao programa, é necessário o cumprimento de diversos requisitos, dispostos no art. $86, \S 1^{\circ}$ da Lei, quais sejam: (i) confessar a prática ilícita; (ii) ser a primeira a se qualificar a confessar a infração noticiada ou sob investigação; (iii) cessar completamente seu envolvimento na infração na data da propositura do acordo; (iv) cooperar de forma plena e permanente com as investigações e com o processo administrativo; e (v) identificar os demais envolvidos. Outro requisito necessário, este alheio ao confessante, é que a autoridade competente não possua elementos probatórios suficientes para assegurar sua condenação no momento da celebração do acordo $^{12}$.

Após celebrado o acordo entre o confessante e o CADE (União), por intermédio da Secretaria de Direito Econômico do Ministério da Justiça $\mathrm{SDE}^{13}$, o confessante (i) estará isento de sanção administrativa no âmbito do CADE pela conduta confessada, caso a autarquia não tivesse conhecimento prévio da prática do ilícito; ou (ii) terá eventual pena administrativa reduzida no valor de um a dois terços, caso o órgão federativo já tenha conhecimento prévio da infração ${ }^{14}$.

$\mathrm{Na}$ esfera criminal, no que tange a crimes contra a ordem econômica (Lei nº 8.137/90) ou crimes tipificados na Lei de Licitações (Lei n 8.666/93), a celebração do acordo de leniência suspende o curso do prazo prescricional e impede o oferecimento de denúncia contra o confessante ${ }^{15}$. Caso o acordo seja integralmente cumprido pelo leniente, extingue-se a punibilidade dos crimes confessados ${ }^{16}$.

\footnotetext{
${ }^{11}$ Nos termos do art. 59 da referida Portaria, o Programa de Leniência brasileiro é "instrumento fundamental para garantir a plena concretização do princípio constitucional da livre concorrência".

12 Cf. art. 86 da Lei n ${ }^{\circ} 12.529 / 11$.

${ }^{13}$ Cf. art. 86 da Lei n ${ }^{\circ} 12.529 / 11$.

${ }^{14}$ Cf. art. $86, \S 4^{\circ}$ da Lei ${ }^{\circ} 12.529 / 11$ e art. 249 do Regimento Interno do CADE.

${ }^{15}$ Cf. art. 87 da Lei $n^{\circ} 12.529 / 11$.

${ }^{16}$ Cf. art. 87, Parágrafo Único da Lei n ${ }^{\circ} 12.529 / 11$.
} 
Em outras palavras, caso o leniente exponha crime ainda não descoberto pelo Estado e cumpra com os termos do acordo, não sofrerá qualquer punição criminal ou administrativa. A escolha do legislador para isentar completamente o confessante se justifica na importância do instituto, como visto acima. Seu objetivo é que tais vantagens, somadas ao temor das sanções impostas em caso de descoberta da prática ilícita por outros meios, atraiam as empresas a informarem condutas ilícitas e celebrarem o acordo sempre que possível, caso estejam envolvidas em atividades ilegais, permitindo a punição dos demais envolvidos.

Importante expor, quanto a tais vantagens, que medidas com o objetivo de aumentar os benefícios aos lenientes acarretam aumento no número de ilícitos descobertos. Para ilustrar este fato, cite-se o ocorrido nos Estados Unidos: após alteração legal que definiu objetivamente os termos da anistia legal no programa de leniência, o número de pedidos para celebração do acordo aumentou em aproximadamente $1.200 \%$, passando de um requerimento por ano para mais de um por mês ${ }^{17}$. Assim, quanto mais benefícios o Estado conceder aos confessantes, a tendência é que mais condutas ilícitas sejam denunciadas.

No entanto, a lei não prevê qualquer isenção de responsabilidade na esfera civil. Assim, caso sejam caracterizados o ato ilícito ${ }^{18}$ e o dano ${ }^{19}$, o leniente terá dever de indenizar todos aqueles que tenham sido prejudicados por sua conduta. Diferentemente de outros países, a legislação brasileira não dispõe sobre limitação de responsabilidade do confessante, pagamento de indenização única à coletividade ou mesmo vedação ao uso de determinados documentos constantes dos autos do acordo de leniência em procedimentos de responsabilidade civil.

Neste ponto, abre-se um parêntesis importante para abordar a questão do sigilo do acordo de leniência. Embora a proposta de acordo e todo seu

17 "The Modern Leniency Program After Ten Years - A Summary Overview of the Antitrust Division's Criminal Enforcement Program". The United States Department of Justice. 2003.

${ }^{18}$ Cf. arts. 186 e 187 do Código Civil.

${ }^{19} \mathrm{Cf}$. art. 927 do Código Civil. 
procedimento sejam sigilosos por força de lei ${ }^{20}$, após o julgamento do procedimento administrativo instaurado para análise do acordo pelo CADE, alguns dados tornam-se públicos. A este respeito, confira-se o Guia do Programa de Leniência do CADE:

\begin{abstract}
"O Cade segue seus procedimentos de confidencialidade do Acordo de Leniência mesmo após o julgamento do processo administrativo pelo Plenário do Tribunal do Cade. O julgamento do processo administrativo torna pública a identidade da empresa e/ou das pessoas físicas beneficiárias do Acordo de Leniência, oportunidade em que também poderão ser divulgadas informações essenciais para a compreensão e deslinde do caso, por meio da divulgação do voto público do Conselheiro Relator. Via de regra, o voto é detalhado e pode incluir informações e imagens dos documentos necessários para a imputação da conduta anticompetitiva a todos os representados, sejam eles Signatários do Acordo de Leniência, Compromissários do TCC ou não. Mesmo após o julgamento pelo Tribunal, o Cade envidará seus melhores esforços para a manutenção da confidencialidade dos documentos e informações submetidos voluntariamente pelo beneficiário do Acordo de Leniência que configurarem segredo comercial das empresas.

Assim, com relação aos terceiros interessados (por exemplo, clientes e consumidores que se sentirem prejudicados pela infração noticiada), o Cade, via de regra, não confere acesso a informações e aos documentos voluntariamente apresentados no âmbito do Acordo de Leniência para além dos que já constam no voto público do Conselheiro Relator. O Cade, todavia, tem o dever de prestar informações, a qualquer tempo, inclusive envolvendo documentos derivados de Acordos de Leniência, se houver ordem judicial nesse sentido. Nesta hipótese, se houver decisão judicial com tal ordem, as informações e os documentos adicionalmente disponibilizados deverão ser de acesso restrito às partes beneficiárias da ordem, no bojo daquela ação específica e não poderão ser disponibilizados a terceiros (inclusive no exterior), sendo que a ProCade intervirá no processo judicial para garantir a manutenção do Programa de Leniência"21.
\end{abstract}

Conforme o próprio CADE admite, (i) fatos importantes acerca do acordo, como a pessoa que o celebrou, seu objeto e detalhes da conduta ilícita, são divulgados pela publicidade do voto do relator; e (ii) não é possível impedir o acesso aos autos de terceiro que se julga lesado pela prática ilícita, caso este consiga decisão judicial para tal. Ou seja, após o julgamento aprovação - do acordo celebrado pelo CADE, abrem-se as portas para a utilização legal dos documentos do acordo para a reparação civil.

Importante ressaltar o peso de tais documentos na lide de responsabilidade civil: essencialmente, ao analisar o caso instruído com os

\footnotetext{
${ }^{20}$ Cf. arts. 49 e $86, \S^{\circ}$ da Lei no $12.529 / 11$ e arts. 91, 241 e 248 do Regimento Interno do CADE.

${ }^{21}$ Guia Programa de Leniência Antitruste do Cade. Ministério da Justiça. Setembro de 2017, p. 53.
} 
autos do procedimento administrativo, o juiz terá uma confissão da prática lesiva pela empresa, homologada pelo próprio Estado. A menos que haja rompimento do nexo de causalidade, dificilmente não será reconhecida lesão sofrida pelo autor desta ação. Assim, restará ao juízo analisar a extensão do dano para determinar a condenação da leniente. Em outras palavras, a divulgação do acordo de leniência pelo CADE acarretará prejuízo à empresa leniente, o que desincentiva a celebração do acordo. Nas palavras de Paulo Renato Jucá22:

\begin{abstract}
"Parece fora de dúvida que a divulgação de dados e documentos sensíveis relacionados ao acordo prejudicará o sucesso do programa de leniência no Brasil, na medida em que, sem uma salvaguarda na esfera cível, o denunciante pode vir a ser acionado para ressarcir todo o prejuízo do cartel em razão da responsabilidade solidária instituída em lei nestas hipóteses. Efetivamente, ao contribuir com o CADE, o denunciante torna-se mais exposto a ações de indenização, colocando-se possivelmente em situação pior do que outros participantes do cartel. Afinal, o denunciante pode ser demandando civilmente e responder integralmente pelo pagamento dos danos causados pela prática anticoncorrencial em virtude da responsabilidade civil solidária".
\end{abstract}

Dessa forma, ao propor a celebração de acordo de leniência, a empresa deverá analisar sua exposição devido ao risco da responsabilidade civil. Para que haja a proposta de acordo ao CADE, é necessário que, no cálculo ao qual se impõe o agente econômico, as vantagens da celebração do acordo superem os danos que eventualmente possam ser sofridos. Dessa forma, a previsão legal de quais seriam tais benefícios e danos é necessária para que o instituto do acordo de leniência continue a crescer.

A falta de disposição legal limitadora da reparação civil nesses casos é fator que pode ser grave à confessante. Imagine-se, por exemplo, a operação de cartel durante três anos que imponha a venda do produto $\mathrm{X}$ por $\mathrm{R} \$ 5,00$, ao passo que seu preço no livre mercado seria, em média, R \$ 4,00. Caso 1\% da população brasileira adquira este produto uma vez por mês (total de 72 milhões de produtos vendidos na duração do cartel), a empresa poderia ser obrigada a indenizar seus consumidores, devido à solidariedade entre os

\footnotetext{
${ }^{22}$ Paulo Renato Jucá. A reparação civil no crime de cartel nas hipóteses de acordo de leniência com o CADE. 2019. No prelo.
} 
participantes do cartel, em $\mathrm{R} \$ 72$ milhões, equivalente a $20 \%$ da receita bruta de todo o cartel. Importante destacar que, caso o cartel dobre o preço do produto, a empresa poderá ser condenada a indenizar os lesados no valor de toda receita operacional que os membros do cartel obtiveram no período. Em outras palavras, a indenização devida, neste caso, poderia ser fatal à empresa.

Outro exemplo de conduta ilegal que poderia ensejar a reparação civil a terceiros seria no caso de fraude a licitação. Caso um grupo de empresas controle o processo licitatório de um determinado setor - como ocorreu no caso da Siemens -, empresa estranha a tal grupo poderia, hipoteticamente, exigir judicialmente os lucros aos quais teria direito caso sua proposta fosse a vencedora em licitação justa. Tal condenação, em setores mais sofisticados como o metroferroviário, poderia ser bilionária.

Assim sendo, restariam poucos incentivos à empresa que pratica atividades concorrenciais ilícitas para que confesse sua atividade, o que não é desejável.

Por outro lado, importante ponderar que a empresa confessante praticou atos lesivos à ordem econômica brasileira, causando diversos danos concorrenciais que devem ser reparados. É direito legal de todos os lesados pela prática ilícita requererem a indenização integral dos danos sofridos, conforme os artigos 927 e 944 do Código Civil ${ }^{23}$, não havendo qualquer previsão legal de relativização deste direito.

Do mesmo modo, cumpre ressaltar que os principais incentivos ao mercado não podem servir somente para que haja a confissão do crime; os mecanismos legais devem apresentar barreiras para que não ocorra o crime. Conforme exposto pelo Conselheiro Fernando de Magalhães Furlan, a

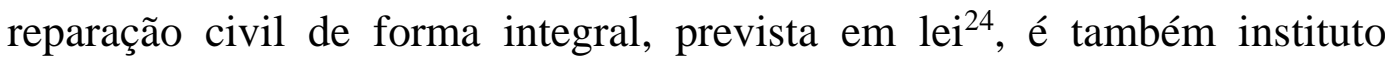
fundamental para que as pessoas não cometam ilícitos concorrenciais em primeiro lugar.

\footnotetext{
23 "Art. 927. Aquele que, por ato ilícito (arts. 186 e 187), causar dano a outrem, fica obrigado a repará-lo"; e "Art. 944. A indenização mede-se pela extensão do dano".

${ }^{24}$ Cf. art. 47 da Lei no $12.529 / 11$.
} 
Portanto, não há uma resposta simples e direta ao problema apresentado. A reparação civil, no caso, funciona como obstáculo à tentativa de acordo de leniência. Se tratando de dois institutos imprescindíveis para o pleno funcionamento e eficiência da sociedade, impossível que um seja afastado para aplicação exclusiva do outro.

Apesar da dificuldade de uma análise estatística sobre as atividades estudadas $^{25}$, um dado interessante demonstra que, a princípio, o atual programa de leniência brasileiro não apresenta incentivos para (i) evitar que as empresas pratiquem atos ilícitos; e (ii) gerar interesse das empresas que cometem crimes concorrenciais na celebração espontânea de acordos de leniência: o número de acordos de leniência celebrados no âmbito do CADE aumentou exponencialmente após 2015, devido à Operação Lava-Jato. Conforme dados do $\mathrm{CADE}^{26}$ :

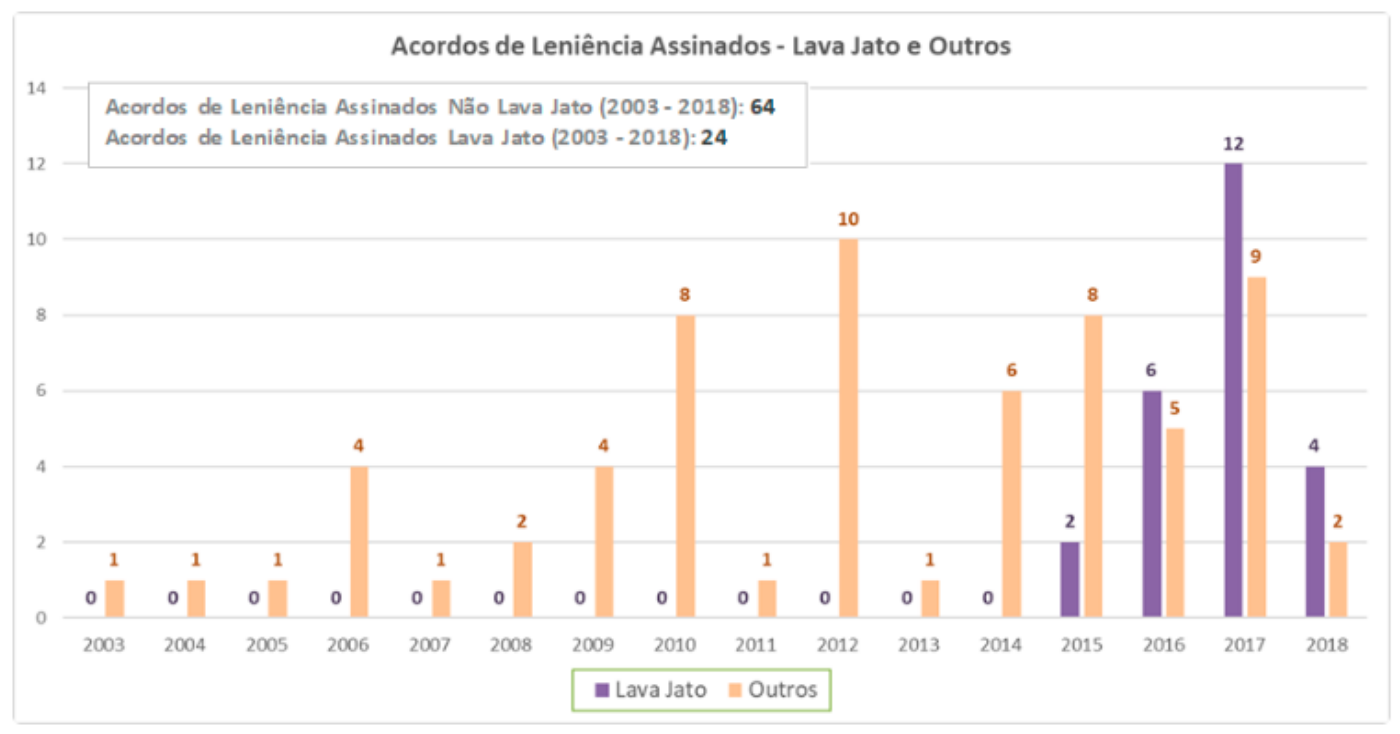

Dos 48 acordos de leniência celebrados no âmbito do CADE de 2015 a meados de 2018, exatamente metade foram assinados apenas em procedimentos relacionados a Operação Lava-Jato, que não foi deflagrada por investigação com base em acordo de leniência.

\footnotetext{
${ }^{25}$ Devido, conforme exposto, ao caráter ilegal das práticas que são objeto da celebração do acordo de leniência.

${ }^{26}$ Fonte: http://www.cade.gov.br/assuntos/programa-de-leniencia. Acesso em 29/03/19, às 18h24.
} 
Isso significa que, apesar dos avanços nas políticas de combate aos crimes concorrenciais, o resultado almejado ainda não foi alcançado. Apenas depois de investigações já em curso, com o alto risco de descoberta da atividade ilegal pelo Estado e diversas delações premiadas e acordos de leniência sendo celebrados, as empresas que praticavam atividades ilícitas se sentiram atraídas a celebrarem seus próprios acordos de leniência. Ou seja, para tais empresas, valia a pena cometer o crime e, anteriormente à ação do Estado, manter a prática ilícita.

Nesse ponto, importante explicar a vantagem para o Estado em celebrar o acordo de leniência nessas condições. Além da economia de recursos aplicados na investigação da infração - o que cessaria após a confissão da empresa leniente -, o CADE terá a comprovação da infração ocorrida, bem como eventual comprovação da prática de ilícitos por outros agentes econômicos (i. e. no caso do crime de cartel) e ainda poderá negociar com o leniente a exposição de ilícito concorrencial em outro setor, não investigado pela autarquia ${ }^{27}$.

Não havendo incentivos eficientes para impedir que a infração concorrencial ocorra nem para fomentar a celebração de acordos de leniência, resta clara a necessidade de alteração no programa de leniência brasileiro, para que se alcance um novo equilíbrio.

$\mathrm{Na}$ busca por esse equilíbrio, diversas questões devem ser analisadas: a importância do acordo de leniência para a descoberta de crimes concorrenciais, o aumento proporcional do número de acordos propostos com relação ao aumento de benefícios legais, a conduta ilícita praticada, o instituto da responsabilidade civil que garante a reparação integral a pessoa que sofre dano decorrente de ato ilícito, a possível e talvez injusta isenção de

\footnotetext{
${ }^{27}$ Essa confissão do leniente de crime concorrencial não investigado ocorre por meio do instituto da Leniência Plus. Nos termos do Programa de Leniência do CADE: "A leniência plus consiste em um benefício de redução em um terço da penalidade aplicável à empresa e/ou à pessoa física que fornecer informações acerca de um novo cartel sobre o qual a Superintendência-Geral do Cade ("SG/Cade") não tinha conhecimento prévio (Novo Acordo de Leniência) (art. $86, \S 7^{\circ}$ e $\S 8^{\circ}$ da Lei $\mathrm{n}^{\circ} 12.529 / 2011 \mathrm{c} / \mathrm{c}$ art. 250 do RICade), quando esta mesma empresa e/ou pessoa física não se qualificar para um Acordo de Leniência com relação a um outro cartel do qual tenha participado (Acordo de Leniência Original)".
} 
qualquer pena, criminal ou administrativa, a quem cometeu um crime continuado. Assim, tal problema deve ser amplamente estudado e discutido para que a sociedade chegue ao desejado equilíbrio entre o incentivo e a punição.

Sobre tal equilíbrio, importante destacar o entendimento do Ministério Público $^{28}$ :

"Neste sentido, é importante atentar que, no Estado Democrático de Direito, a sanção não é fim em si mesmo. Ostenta caráter instrumental e, como tal, deve consistir num meio necessário, suficiente e indispensável, mas sempre proporcional, para justificar sua imposição a um particular na repressão a conduta ilícita. Do mesmo modo, o acordo de leniência, método alternativo de investigação e negociação entre Estado e particular, deve corresponder a um desejável equilíbrio entre efetividade e eficiência administrativa no combate a delitos, de um lado, e integridade, consistência e coerência do agir estatal em todos os âmbitos, inclusive no repressivo, de outro"

A análise e o conhecimento das questões expostas acima são fundamentais para que a empresa que pratica o crime concorrencial pese se é vantajosa a manutenção da prática do ato ilícito ou se prefere a denúncia de tais atividades. Do mesmo modo, é imperativo que o Estado as considere na tentativa de impedir eventuais infrações legais e garantir que todas as infrações ocorridas sejam descobertas.

Portanto, é fundamental que o legislador e os órgãos da administração pública, ao elaborarem, implementarem e desenvolverem o programa de leniência brasileiro, considerem todos os elementos apresentados para garantir o melhor resultado possível. O objetivo deste programa de leniência, como visto, deve ser criar mecanismos que impeçam a prática dos crimes estudados $^{29}$ e, se por acaso eles ocorrerem, que sejam confessados o mais cedo possível por seus atores, levando em conta os interesses individuais e coletivos lesados pela conduta ilícita.

\footnotetext{
${ }^{28}$ Estudo Técnico n ${ }^{0}$ 01/2017. $5^{\mathrm{a}}$ Câmara de Coordenação e Revisão do Ministério Público Federal - Combate à Corrupção. Disponível em https://bit.ly/2JxMQdG. Consultado em 22.03.19, às 18h55.

${ }^{29}$ Este deve ser o objetivo de todo o sistema de defesa da concorrência brasileiro, conforme positivado pela Lei $n^{\circ} 12.529 / 11$, não apenas do programa de leniência.
} 


\title{
3. Características do Pleito Indenizatório
}

\subsection{Responsabilidade Civil Concorrencial}

Caso a conduta ilícita do agente econômico cause danos a terceiros, sejam estes de cunho patrimonial ou moral, nasce sua obrigação em reparálos. O instituto do direito que fundamenta tal obrigação é a responsabilidade civil, que será estudada em termos gerais neste capítulo para que sejam analisados os requisitos necessários para a reparação civil do dano concorrencial.

Como exposto acima, responsabilidade civil funciona como fonte de obrigação no direito civil brasileiro, para que o dano causado por determinado agente seja integralmente reparado. Nas palavras de Caio Mário da Silva Pereira ${ }^{30}$ :

\begin{abstract}
"A responsabilidade civil consiste na efetivação da reparabilidade abstrata do dano em relação ao sujeito passivo da relação jurídica que se forma. Reparação e sujeito passivo compõe o binômio da responsabilidade civil, que então se enuncia como o princípio que subordina a reparação à sua incidência na pessoa do causador do dano”.
\end{abstract}

O Código Civil prevê a regra geral de reponsabilidade civil em seus arts. 186 e 927, assim dispondo:

“Art. 186. Aquele que, por ação ou omissão voluntária, negligência ou imprudência, violar direito e causar dano a outrem, ainda que exclusivamente moral, comete ato ilícito"; e

“Art. 927. Aquele que, por ato ilícito (arts. 186 e 187), causar dano a outrem, fica obrigado a repará-lo.

Parágrafo único. Haverá obrigação de reparar o dano, independentemente de culpa, nos casos especificados em lei, ou quando a atividade normalmente desenvolvida pelo autor do dano implicar, por sua natureza, risco para os direitos de outrem".

Visando conferir mais garantias quanto ao ressarcimento dos lesados e a punição aos agentes que cometem ilícitos concorrenciais, a Lei da

\footnotetext{
${ }^{30}$ Caio Mário da Silva Pereira. Responsabilidade Civil. Rio de Janeiro: Forense. 2016. 11 a edição. p. 14.
} 
Concorrência também dispôs, em seu art. 47, sobre a obrigação do agente infrator em indenizar os danos sofridos por terceiros decorrentes de sua conduta:

\begin{abstract}
“Art. 47. Os prejudicados, por si ou pelos legitimados referidos no art. 82 da Lei no 8.078 , de 11 de setembro de 1990 , poderão ingressar em juízo para, em defesa de seus interesses individuais ou individuais homogêneos, obter a cessação de práticas que constituam infração da ordem econômica, bem como o recebimento de indenização por perdas e danos sofridos, independentemente do inquérito ou processo administrativo, que não será suspenso em virtude do ajuizamento de ação".
\end{abstract}

Assim, a Lei da Concorrência insere a reparação civil por dano concorrencial no sistema de direito concorrencial brasileiro ${ }^{31}$.

Ademais, tal dispositivo não prevê qualquer caráter punitivo à indenização. Desta forma, o agente infrator estará sujeito somente ao pagamento de perdas e danos aos lesados, ressarcindo-os somente pelos danos que causou, em sua medida exata, observando o art. 944 do Código Civil $^{32}$.

Cumpre ressaltar, ainda, que o art. 36 da Lei da Concorrência prevê a responsabilidade objetiva pelas condutas anticoncorrenciais. Ao assim fazer, dispôs que os agentes que cometem crimes concorrenciais respondam objetivamente pelos danos causados, sem análise de culpa do agente econômico, na forma do disposto no art. 927, Parágrafo Único do Código Civil. Em estudo sobre a responsabilidade civil objetiva, expôs Caio Mário da Silva Pereira ${ }^{33}$ :

\footnotetext{
"A doutrina objetiva, ao invés de exigir que a responsabilidade civil seja resultante dos elementos tradicionais (culpa, dano, vínculo de causalidade entre um e outro) assenta na equação binária cujos polos são o dano e a autoria do evento danoso. Sem cogitar da imputabilidade ou investigar a antijuridicidade do fato danoso, o que importa para assegurar o ressarcimento é a verificação se ocorreu o evento e se dele emanou o prejuízo. Em tal ocorrendo, o autor do fato causador do dano é o responsável".
}

\footnotetext{
${ }^{31}$ Tércio Sampaio Ferraz Júnior. Direito da Concorrência e Enforcement Privado na Legislação Brasileira. In Revista de Defesa da Concorrência, v. I, nº 2, novembro de 2013, p. 21.

32 "Art. 944. A indenização mede-se pela extensão do dano".

${ }^{33}$ Caio Mário da Silva Pereira. Responsabilidade Civil. Rio de Janeiro: Forense. 2016. 11 edição. p. 352 .
} 
Leitura conjugada de ambos dispositivos legais presentes na Lei de Concorrência permite concluir que, para fins de configuração do dever de indenizar, basta a conduta ilícita e a comprovação do dano decorrente desta conduta.

Resta, neste ponto, analisar a caracterização dos requisitos intrínsecos da responsabilidade civil no dano concorrencial.

\subsubsection{Ato ilícito, nexo causal e dano no crime concorrencial}

Como já visto, o art. 186 do Código Civil assim dispõe: "aquele que por ação ou omissão voluntária, negligência ou imprudência, violar direito e causar dano a outrem, ainda que exclusivamente moral, comete ato ilícito".

A partir do dispositivo legal, pode-se entender como ato ilícito a ação ou omissão do agente que impõe sua obrigação de indenizar quem dela sofreu danos. Assim sendo, é possível desconstruir o ato ilícito em três elementos: (a) a conduta antijurídica; (b) o nexo de causalidade; e (c) o dano ${ }^{34}$.

Em seu estudo sobre a responsabilidade civil, Sergio Cavalieri Filho expõe dois sentidos para o termo ato ilícito: (a) em sentido estrito, no qual o termo é definido como "o conjunto de pressupostos da responsabilidade"; e (b) em sentido amplo, no qual ato ilícito é conceituado como " $a$ conduta humana antijurídica, contrária ao direito, sem qualquer referência ao elemento subjetivo ou psicológico" ${ }^{35}$.

No âmbito do artigo 186 do Código Civil, se utiliza ato ilícito em seu sentido amplo. Conforme expõe Humberto Theodoro Junior ${ }^{36}$ :

\footnotetext{
"O direito se constitui como um projeto de convivência, dentro de uma comunidade civilizada (o Estado), no qual se estabelecem os padrões de comportamento necessários. A ilicitude ocorre quando in concreto a pessoa se comporta fora desses padrões. Em sentido lato, sempre que alguém se afasta do programa de

${ }^{34}$ Anderson Schreiber et al. Código Civil Comentado: Doutrina e Jurisprudência. Rio de Janeiro: Forense, 2019, p. 113.

35 Sergio Cavalieri Filho. Programa de Responsabilidade Civil. São Paulo: Malheiros, 6 ${ }^{\mathrm{a}}$ edição, 2006, p. 32/33.

${ }^{36}$ Humberto Theodoro Junior. Comentários ao Novo Código Civil: Dos atos jurídicos lícitos. Dos atos ilícitos. Da prescrição e da decadência. Da prova. Arts. 185 a 232. Vol. III, Tomo II. Coord. Sálvio de Figueiredo Teixeira. Rio de Janeiro: Forense, 2008, p. 18.
} 
comportamento idealizado pelo direito positivo, seus atos voluntários correspondem, genericamente, a atos ilícitos (fatos do homem atritantes com a lei). Há, porém, uma ideia mais restrita de ato ilícito, que se prender, de um lado ao comportamento injurídico do agente, e de outro ao resultado danoso que dessa atitude decorre para outrem. Fala-se, então, em ato ilícito em sentido estrito, ou simplesmente ato ilícito, como se faz no art. 186do atual Código Civil. Nesse aspecto, a ilicitude não se contentaria com a ilegalidade do comportamento humano, mas se localizaria, sobretudo, no dano injusto a que o agente fez a vítima se submeter".

Assim sendo, para caracterização do ato ilícito, é necessária a configuração de dano decorrente da ação ou omissão do agente.

No âmbito concorrencial, o ato ilícito aqui estudado ocorre na violação, por uma empresa ou por grupo de companhias, do disposto no art. 36 da Lei de Concorrência ${ }^{37}$. Como visto, o próprio caput do dispositivo legal determina que conduta neste sentido configura "infração da ordem econômica", sendo assim conduta antijurídica e, havendo dano, caracterizador de responsabilidade.

O nexo causal, conceito fático-jurídico, se verifica na relação entre o ato ilícito e o dano causado. Para que se comprove o nexo causal, cumpre fazer a análise do evento: caso o dano sofrido ocorresse independentemente do ato ilícito, não há nexo entre ambos. Por outro lado, caso o dano tenha ocorrido devido ao ato ilícito, está comprovado o nexo de causalidade no caso. Conforme Carlos Alberto Menezes Direito e Sergio Cavalieri Filho ${ }^{38}$.

\footnotetext{
"O conceito de nexo causal não é exclusivamente jurídico; decorre primeiramente das leis naturais. É o vínculo, a ligação ou a relação de causa e efeito entre a conduta e o resultado. A relação causal estabelece o vínculo entre um determinado comportamento e um evento, permitindo concluir, com base nas leis naturais, se a ação ou omissão do agente foi ou não foi a causa do dano; determina se o resultado surge como consequência natural da voluntária conduta do agente. Algo assim como: se chover fica molhado.
}

\footnotetext{
37 “Art. 36. Constituem infração da ordem econômica, independentemente de culpa, os atos sob qualquer forma manifestados, que tenham por objeto ou possam produzir os seguintes efeitos, ainda que não sejam alcançados:

I - limitar, falsear ou de qualquer forma prejudicar a livre concorrência ou a livre iniciativa;

II - dominar mercado relevante de bens ou serviços;

III - aumentar arbitrariamente os lucros; e

IV - exercer de forma abusiva posição dominante".

${ }^{38}$ Carlos Alberto Menezes Direito e Sergio Cavalieri Filho. Comentários ao Novo Código Civil: Da responsabilidade civil, das preferências e privilégios creditórios. Arts. 927 a 965. Vol. XIII. Coord. Sálvio de Figueiredo Teixeira. Rio de Janeiro: Forense, 2011, $3^{\text {a }}$ edição, p. 76.
} 
Mas o nexo causal, além desse elemento naturalístico, exige também uma avaliação jurídica pelo juiz para verificar, com precisão, a relação entre certo fato $r$ determinado resultado. Veremos que é um processo técnico de probabilidade. O juiz tem que eliminar os fatos que foram irrelevantes para a efetivação do dano. $\mathrm{O}$ critério eliminatório consiste em estabelecer que, mesmo na ausência desses fatos, o dano ocorreria. Causa será aquela que, após esse processo de expurgo, se revelar a mais idônea para produzir resultado.

Em suma, o nexo causal é um elemento referencial entre a conduta e o resultado. É o conceito jurídico-normativo através do qual poderemos concluir quem foi o causador do dano".

No exemplo exposto no capítulo anterior, o nexo de causalidade se verificaria na medida em que, a partir do aumento de preços de forma cartelizada (ato ilícito), o consumidor do produto $\mathrm{X}$ se submeteu ao pagamento ilegal, durante três anos, de $\mathrm{R} \$ 1,00$ por cada compra do produto. Caso o mercado do produto $\mathrm{X}$ fosse legal, não havendo o cartel, seu consumidor pagaria somente $\mathrm{R} \$ 4,00$ pelo bem. Portanto, resta caracterizado o nexo de causalidade entre a conduta ilícita e o dano sofrido no exemplo analisado.

Por fim, resta análise do dano para que seja configurada a responsabilidade do agente infrator.

Para conceituação de "dano", precisa a definição de Gustavo Tepedino, Heloiza Helena Barbosa e Maria Celina Bodin de Moraes ${ }^{39}$ :

"O dano é também elemento essencial do ato ilícito e da responsabilidade civil. Cuidando-se de elemento essencial do ato ilícito, fonte da responsabilidade civil, sem dano não há ato ilícito, ainda que se esteja diante de conduta antijurídica. Na célebre frase de Henri Lalou, 'pas de préjudice, pas de responsabilité civile'.

Define-se o dano como a lesão a um bem jurídico. A doutrina ressalva, todavia, que nem todo dano é ressarcível. Necessário se faz que seja certo e atual. Certo é o dano não hipotético, ou seja, determinado ou determinável. Atual é o dano já ocorrido ao tempo da responsabilização. Vale dizer: em regra, não se indeniza o dano futuro, pela simples razão de que dano ainda não há. Diz-se 'em regra' porque a evolução social fez surgir questões e anseios que desafiam a ideia de irreparabilidade do dano futuro. Inúmeras hipóteses de 'novos danos', próprios da sociedade tecnológica, apresentam lesões a bens jurídicos que, segundo especialistas, configurarão danos projetados para o futuro, ainda que não identificados no momento presente".

${ }^{39}$ Gustavo Tepedino, Heloiza Helena Barbosa e Maria Celina Bodin de Moraes. Código Civil Interpretado de Acordo com a Constituição da República. Vol. I, Parte Geral e Obrigações (arts. $1^{\circ}$ a 420). Rio de Janeiro: Renovar, 2004, p. 334. 
No direito concorrencial, o dano se configura, por óbvio, na lesão sofrida devido à conduta ilícita do agente econômico. Conforme visto no capítulo 2, os lesados em decorrência de cartel seriam, por exemplo, os consumidores e eventual empresa que foi prejudicada em seu mercado devido à organização ilegal. Segundo Bruno Oliveira Maggi40:

"No caso dos cartéis, tem-se que o ato ilícito é o acordo entre os agentes de mercado, o dano é composto pelas alterações sofridas pelo mercado em razão das decisões do cartel e o efeito (prejuízo) é o pagamento pelos compradores de valor acima do que normalmente seria cobrado pelo bem, além dos demais efeitos relacionados à perda do mercado"

No entanto, é possível analisar outras condutas lesivas da prática do cartel, não individuais. Uma delas, por exemplo, é a falta de investimento em pesquisa e desenvolvimento ${ }^{41}$, limitando a evolução do mercado cartelizado.

Do mesmo modo, não é difícil constatar o dano decorrente de perda da eficiência do mercado analisado devido ao desinvestimento das empresas cartelizadas em áreas de produção, marketing e propaganda. Ou mesmo o dano sofrido por ente público em razão de fraude à licitação em mercado cartelizado.

Portanto, o dano é, em suma, o prejuízo causado pelo ato ilícito, qualquer seja sua natureza.

O dano deve ser analisado de acordo com cada ato ilícito. Assim sendo, deve-se analisar o crime concorrencial no caso concreto para averiguação de suas consequências e dos bens jurídicos de terceiros lesados pela conduta ilícita do agente econômico.

\subsection{Prescrição}

40 Bruno Oliveira Maggi. Cartel: Reponsabilidade Civil Concorrencial. São Paulo: Thomson Reuters, 2018, p. 188.

${ }^{41}$ Com o controle do mercado assegurado, não havendo livre concorrência, não há incentivo às empresas investirem em inovações que visem obter uma vantagem concorrencial lícita em relação à concorrência. 
Analisa-se agora o efeito da prescrição no âmbito do dano civil concorrencial. O prazo legal para que ocorra a prescrição da indenização seria de três anos, na forma do art. 206, $\S 3^{\circ}$, V do Código Civil ${ }^{42}$.

Quanto ao seu termo inicial, não há dúvida que o prazo prescricional é contado a partir da ciência do ato ilícito e seus efeitos pelo lesado, conforme reconhecido pela jurisprudência ${ }^{43}$.

Cumpre ressaltar que, no caso de prática de ilícitos concorrenciais que também tenham reflexo na esfera criminal - como, por exemplo, o cartel -, há causa impeditiva à prescrição, por força do art. 200 do Código Civil ${ }^{44}$.

Questão interessante que versa sobre tal dispositivo ocorre quando, apesar de o lesado já ter ciência do ato ilícito e de seus efeitos, ação penal para apurar a conduta criminosa sequer tenha sido ajuizada ainda. Nesse caso, a jurisprudência do STJ se posiciona no sentido de que, para aplicação do dispositivo legal, é necessário que esteja em curso ao menos inquérito policial. Confira-se ${ }^{45}$ :

"RECURSO ESPECIAL. RESPONSABILIDADE CIVIL. ACIDENTE DE TRÂNSITO. PRESCRIÇÃO DA PRETENSÃO INDENIZATÓRIA. SUSPENSÃO PREVISTA NO ARTIGO 200 DO CÓDIGO CIVIL. NECESSIDADE DE INSTAURAÇÃO DE INQUÉRITO POLICIAL OU DE AÇÃO PENAL. INAPLICABILIDADE DA REGRA AO CASO.

1. Ação de reparação de danos derivados de acidente de trânsito ocorrido em 26 de agosto de 2002 proposta apenas em 07 de fevereiro de 2006, ensejando o reconhecimento pela sentença da ocorrência da prescrição trienal do art. 206 do CC.

\footnotetext{
42 “Art. 206. Prescreve: (...)

$\S 3^{\circ}$ Em três anos: (...)

V - a pretensão de reparação civil".

43 “DIREITO CIVIL. RESPONSABILIDADE CIVIL. RECURSO ESPECIAL. INDENIZAÇÃO EM VIRTUDE DE DANOS MATERIAIS E MORAIS ORIUNDOS DE CONTAMINAÇÃO AMBIENTAL. PRESCRIÇÃO. TERMO INICIAL. NÃO OCORRÊNCIA DA PRESCRIÇÃO. (...) 2. Na responsabilidade contratual, em regra, o termo inicial da contagem dos prazos de prescrição encontra-se na lesão ao direito, da qual decorre o nascimento da pretensão, que traz em seu bojo a possibilidade de exigência do direito subjetivo violado, nos termos do disposto no art. 189 do Código Civil, consagrando a tese da actio nata no ordenamento jurídico pátrio. 3. Contudo, na responsabilidade extracontratual, a aludida regra assume viés mais humanizado e voltado aos interesses sociais, admitindo-se como marco inicial não mais o momento da ocorrência da violação do direito, mas a data do conhecimento do ato ou fato do qual decorre o direito de agir, sob pena de se punir a vítima por uma negligência que não houve, olvidando-se o fato de que a aparente inércia pode ter decorrido da absoluta falta de conhecimento do dano. Inteligência da Súmula 278 do STJ" (STJ, REsp 1.354.348, rel. Min. Luis Felipe Salomão, Quarta Turma, j. 26.08.14).

44 “Art. 200. Quando a ação se originar de fato que deva ser apurado no juízo criminal, não correrá a prescrição antes da respectiva sentença definitiva".

${ }^{45}$ STJ, REsp 1.180.237, Rel. Min. Paulo de Tarso Sanseverino, Terceira Turma, j. 19.06.12
} 
2. Reforma da sentença pelo acórdão recorrido, aplicando a regra do art. 200 do CC de 2002.

3. Inaplicabilidade da regra do art. 200 do $\mathrm{CC} / 2002$ ao caso, em face da inocorrência de relação de prejudicialidade entre as esferas cível e criminal, pois não instaurado inquérito policial ou iniciada ação penal.

4. Interpretação sistemática e teleológica do art. 200 do CC/2002, com base na doutrina e na jurisprudência cível e criminal desta Corte.

5. RECURSO ESPECIAL PROVIDO”.

Em seu voto, o Min. Paulo de Tarso Sanseverino asseverou que "é fundamental que exista processo penal em curso ou, pelo menos, a tramitação de inquérito policial até o seu arquivamento".

Portanto, no caso apresentado, o prazo prescricional flui a partir da data de ciência, pelo lesado, do ato ilícito e de suas consequências. No entanto, caso a ação penal - ou inquérito policial, conforme jurisprudência do STJ -, seja ajuizada durante o curso do prazo, deverá ser aplicado o art. 200 do Código Civil, interrompendo-se sua contagem. Conforme aduzido por Frederico Bastos Pinheiro Martins ${ }^{46}$, "tal entendimento jurisprudencial consolidado consagra a tese de que não é possível fluir o prazo prescricional sem inércia do titular do direito violado, e que tal inação apenas pode ser presumida com a existência de certeza jurídica acerca da violação do direito". Portanto, não há dúvida que, tendo sido instaurado inquérito policial, interrompe-se a contagem do prazo prescricional.

Nesse ponto, impõe-se a análise de eventual causa impeditiva da prescrição da reparação civil por força de procedimento no âmbito administrativo. Como é cediço, é competência do Tribunal Plenário do CADE a análise de infrações concorrenciais ${ }^{47}$. Assim, haveria certeza da prática de ato ilícito apenas após decisão proferida pela autarquia. Aplicandose a tese exposta no parágrafo acima, o prazo prescricional só poderia ser contado a partir de decisão definitiva acerca da infração concorrência - ou do julgamento de acordo de leniência - no âmbito do CADE.

\footnotetext{
${ }^{46}$ MARTINS, Frederico Bastos Pinheiro. Obstáculos às ações privadas de reparação de danos decorrentes de cartéis. FGV (Mestrado). 2017, p. 25.

${ }^{47}$ Lei no 12.529/11: “Art. $9^{\circ}$ Compete ao Plenário do Tribunal, dentre outras atribuições previstas nesta Lei: (...)

II - decidir sobre a existência de infração à ordem econômica e aplicar as penalidades previstas em lei".
} 
Apesar de ainda não haver disposição legal expressa nesse sentido, importante expor os riscos aos quais os lesados pela conduta ilícita estarão sujeitos caso esse entendimento não seja adotado. Não é difícil imaginar, pela complexidade dos atos que devem ser analisados pela autarquia, que o trâmite da apuração de ilícitos concorrenciais demande tempo, bem como para negociação, celebração e julgamento do acordo de leniência. Caso o prazo prescricional corra concomitantemente ao procedimento administrativo, em muitas situações aquele que se julga lesado se encontrará entre a cruz e a espada: ou seu eventual direito à reparação não será mais exigível no momento em que o ato ilícito for reconhecido ou deverá ajuizar uma ação de responsabilidade civil extremamente precária, sem que o ato ilícito tenha sequer sido reconhecido ainda e sem que o autor tenha acesso, presumidamente, a qualquer prova da conduta.

\subsection{Legitimidade Ativa e Passiva}

Via de regra, a pessoa legítima para exigir a indenização é quem sofreu o dano causado pelo ato ilícito. $\mathrm{O}$ art. 47 da Lei de Concorrência nomeia como legítimos (i) os "prejudicados"; e (ii) o rol de entes jurídicos elencado no art. 82 do Código de Defesa do Consumidor ${ }^{48}$. Por se tratar de estudo sobre a indenização civil privada no âmbito do dano concorrencial, este trabalho focará somente nos considerados "prejudicados" nos termos da Lei de Concorrência.

Ao comentar o dispositivo estudado, Tercio Sampaio Ferraz Junior assim define o termo "prejudicados" ${ }^{49}$ :

\footnotetext{
48 “Art. 82. Para os fins do art. 81, parágrafo único, são legitimados concorrentemente:

I - o Ministério Público,

II - a União, os Estados, os Municípios e o Distrito Federal;

III - as entidades e órgãos da Administração Pública, direta ou indireta, ainda que sem personalidade jurídica, especificamente destinados à defesa dos interesses e direitos protegidos por este código;

IV - as associações legalmente constituídas há pelo menos um ano e que incluam entre seus fins institucionais a defesa dos interesses e direitos protegidos por este código, dispensada a autorização assemblear".

${ }^{49}$ Tércio Sampaio Ferraz Júnior. Direito da Concorrência e Enforcement Privado na Legislação Brasileira. In Revista de Defesa da Concorrência, v. I, nº 2, novembro de 2013, p. 21/22.
} 


\begin{abstract}
“A norma nomeia, como sujeitos legitimados, os 'prejudicados'. Os prejudicados são aqueles que sofrem prejuízo pela violação de seus interesses individuais ou individuais homogêneos, por força de práticas que constituam infração da ordem econômica. Isto é, mesmo em sede de interesses individuais, não são danos marcados pelo subjetivismo privatista enquanto danos resultantes do descumprimento de obrigação, contratual ou legal, e que tenha por causa o inadimplemento de obrigação contratual, o dever contratual de responder pelo risco ou dever legal de responder sem culpa, sempre em termos de nexo causal cujo núcleo é a ação subjetiva: consequência da conduta de quem o produziu. Mas sim são danos resultantes de condutas em relações econômicas definidas diretamente pelo poder (exclusão e colusão), ou porque as condutas visam à construção de situações de poder ou porque se originam de situação de poder e, em ambos os casos, os autores levam vantagem disso. Ou seja, prejuízos cujo núcleo causal está não na propriedade (em sentido privatista de conduta individual e individualizável), mas na competição (em sentido de interesse difuso: seus interesses individuais ou individuais homogêneos), mas individualizados no agente econômico que os sofre".
\end{abstract}

Também analisando o art. 47 da Lei de Concorrência, Daniel Costa Caselta expôs que não se deve limitar a interpretação de "prejudicados" somente àqueles que sofreram danos diretamente decorrentes do ato ilícito. Não fazendo a lei qualquer distinção, compradores indiretos também possuem direito de exigir ressarcimento pelo prejuízo sofrido em decorrência do ato ilícito, devido ao repasse, na cadeia de consumo, do sobrepreço ${ }^{50}$.

Assim, o comprador de um carro que tenha sido fabricado com motor adquirido pela montadora em mercado cartelizado com controle de preços, por exemplo, também poderia exigir ressarcimento do sobrepreço no valor do carro causado pelo aumento indevido do custo do motor, repassado ao consumidor final pela montadora.

Portanto, segundo o art. 47 da lei de Concorrência, é legítimo para exigir reparação dos danos sofridos por conduta anticoncorrencial todos os que sofreram lesão decorrente do ato ilícito, seja de forma direta ou de forma indireta.

Quanto à legitimidade passiva, o art. 31 da Lei de Concorrência assim dispõe:

\footnotetext{
${ }^{50}$ Daniel Costa Caselta. Responsabilidade civil por danos decorrentes da prática de cartel. USP (Mestrado), 2015, p. 88.
} 
"Art. 31. Esta Lei aplica-se às pessoas físicas ou jurídicas de direito público ou privado, bem como a quaisquer associações de entidades ou pessoas, constituídas de fato ou de direito, ainda que temporariamente, com ou sem personalidade jurídica, mesmo que exerçam atividade sob regime de monopólio legal”.

Pelo dispositivo legal, o art. 47 da Lei de Concorrência seria aplicável contra qualquer agente acima elencado. Para isso, basta que tenha causado o dano que demanda a reparação civil concorrencial ou, como se verá a seguir, atue ilicitamente em conjunto com pessoa diretamente responsável pelo dano sofrido.

\subsection{Solidariedade no crime concorrencial}

Importante notar, ainda, que há solidariedade passiva entre os diversos agentes que atuam em conluio na prática de crime concorrencial ${ }^{51}$. No caso, a responsabilidade solidária decorreria de lei, nos termos do art. 942, parágrafo único do Código Civil:

“Art. 942. Os bens do responsável pela ofensa ou violação do direito de outrem ficam sujeitos à reparação do dano causado; e, se a ofensa tiver mais de um autor, todos responderão solidariamente pela reparação.

Parágrafo único. São solidariamente responsáveis com os autores os co-autores e as pessoas designadas no art. $932^{52 \%}$.

Com a aplicação desse dispositivo, os agentes que concorrem para a prática do crime concorrencial - como os membros de um cartel, por exemplo -, seriam considerados "co-autores" e, portanto, responsáveis pelo ressarcimento integral do dano, tendo, caso arquem com a integralidade do

\footnotetext{
${ }^{51}$ Neste sentido: Daniel Costa Caselta. Responsabilidade civil por danos decorrentes da prática de cartel. USP (Mestrado), 2015, p. 109; Bruno Oliveira Maggi. O cartel e seus efeitos na responsabilidade civil. USP (Mestrado), 2010, p. 167

$52 \mathrm{O}$ art. 932 do Código Civil assim dispõe:

“Art. 932. São também responsáveis pela reparação civil:

I - os pais, pelos filhos menores que estiverem sob sua autoridade e em sua companhia;

II - o tutor e o curador, pelos pupilos e curatelados, que se acharem nas mesmas condições;

III - o empregador ou comitente, por seus empregados, serviçais e prepostos, no exercício do trabalho que lhes competir, ou em razão dele;

IV - os donos de hotéis, hospedarias, casas ou estabelecimentos onde se albergue por dinheiro, mesmo para fins de educação, pelos seus hóspedes, moradores e educandos;

$\mathrm{V}$ - os que gratuitamente houverem participado nos produtos do crime, até a concorrente quantia".
} 
débito, direito de regresso contra os demais co-autores por força do art. 283 do Código Civil ${ }^{53}$.

Trata-se de importante medida para coibir a prática de atividades concorrenciais ilícitas por grupos de agentes econômicos. No entanto, conforme exposto no capítulo 2 , tal responsabilidade desincentiva agentes econômicos que já praticam tal crime de denunciá-lo, visto que ainda seriam responsáveis por todo o dano causado pelo grupo ${ }^{54}$.

Para ilustrar essa afirmação, basta imaginar notícia divulgada na imprensa informando que a empresa $\mathrm{S}$ celebrou Acordo de Leniência com o CADE, denunciando cartel no setor de mercado T. Sem qualquer outra informação, consumidores que consumiram produtos naquele setor poderiam ajuizar ação de indenização contra a empresa $S$, requerendo restituição por eventuais danos que tenham sofrido, independentemente de serem ou não clientes da companhia S. O mesmo poderia fazer o Ministério Público, conforme exemplo visto no capítulo 1, e os demais legitimados do art. 82 do Código de Defesa do Consumidor, em sede de ação coletiva.

Portanto, o risco de ser devedor solidário, obrigado ao ressarcimento integral do dano causado pelo grupo anticoncorrencial, será sempre considerado pelo agente econômico ao avaliar a possibilidade de denunciar a conduta ilícita. Conforme se verá nos capítulos seguintes, mudança neste aspecto da lei poderá ser de grande ajuda no combate aos crimes concorrenciais brasileiros.

\subsection{Prova decorrente de acordo de leniência}

Por fim, cumpre destacar característica vital ao ressarcimento do prejudicado, quando há acordo de leniência celebrado entre um dos agentes infratores e o CADE: a produção de prova.

\footnotetext{
53 “Art. 283. O devedor que satisfez a dívida por inteiro tem direito a exigir de cada um dos codevedores a sua quota, dividindo-se igualmente por todos a do insolvente, se o houver, presumindose iguais, no débito, as partes de todos os co-devedores".

${ }^{54}$ Estudo Técnico no 01/2017. $5^{\text {a }}$ Câmara de Coordenação e Revisão do Ministério Público Federal

- Combate à Corrupção, p. 102.
} 
Conforme já foi exposto, em muitos casos o caráter ilegal e clandestino do crime concorrencial cria uma assimetria de informação acerca da comprovação e da quantificação de dano causado a terceiro. A característica de confidencialidade do acordo de leniência, fundamental, como visto, para garantir a eficiência dos incentivos para celebração do acorda, funciona como impedimento para que o dano causado seja reparado. Não havendo disposição legal que defina uma regra específica em tais casos, resta ao judiciário ponderar a legislação aplicável e o interesse social para achar uma solução.

Em março de 2016 o STJ julgou Recurso Especial interposto pela Whirlpool S.A. e pela Brasmotor S.A. contra a Electrolux do Brasil S.A. cujo objeto era a possibilidade de juntada aos autos dos documentos constantes do acordo de leniência celebrado entre as recorrentes e o CADE. Confira-se a ementa do julgado 55 :

PROCESSO CIVIL. RECURSO ESPECIAL. AÇÃO DE REPARAÇÃO DE DANOS MATERIAIS. DILAÇÃO PROBATÓRIA. DEVER DE COLABORAÇÃO. JUNTADA DE DOCUMENTOS. PROCEDIMENTO ADMINISTRATIVO. ACORDO DE LENIÊNCIA. SIGILO. EXTENSÃO. LIMITES. OPOSIÇÃO AO PODER JUDICIÁRIO. RECURSO ESPECIAL NÃO PROVIDO.

1. Ação de reparação de danos materiais proposta na origem, na qual se pretende a indenização por danos decorrentes de conduta de concerto de preços em mercado relevante, na qual se requereu a juntada de documentos obtidos por meio de acordo de leniência e inquérito policial.

2. No que tange à obtenção de documentos sob guarda de juízo criminal, a posterior apreciação da questão trazida sob a alegação de ofensa ao art. 535 do CPC e interposição de novo recurso especial resulta na perda superveniente do interesse recursal, prejudicando o julgamento do recurso especial interposto por Electrolux do Brasil S.A.

3. O acordo de leniência é instituto destinado a propiciar a obtenção de provas da prática de condutas anticoncorrenciais, por meio do qual se concede ao coautor signatário benefícios penais e administrativos.

4. Nos termos da legislação, assegura-se o sigilo das propostas de acordo de leniência, as quais, eventualmente rejeitadas, não terão nenhuma divulgação, devendo ser restituídos todos os documentos ao proponente.

5. Aceito e formalizado o acordo de leniência, a extensão do sigilo somente se justificará no interesse das apurações ou em relação a documentos específicos cujo segredo deverá ser guardado também em tutela da concorrência.

6. Todavia, ainda que estendido o sigilo, não se pode admitir sua protração indefinida no tempo, perdendo sentido sua manutenção após esgotada a fase de

${ }^{55}$ STJ, REsp 1.554.986, Rel. Min. Marco Aurélio Bellizze, Terceira Turma, j. 08.03.19. 
apuração da conduta, termo marcado pela apresentação do relatório circunstanciado pela Superintendência-Geral ao Presidente do Tribunal Administrativo.

7. O dever geral de colaboração para elucidação dos fatos, imposto nos termos do art. 339 do CPC, somente é afastado por meio de regras expressas de exclusão, entre as quais o sigilo profissional calcado na necessidade precípua de manutenção da relação de confiança inerente a determinadas profissões, o que não se afigura razoável na hipótese dos autos em que a relação entre signatários do acordo e a entidade pública se vinculam por meio do exercício do poder de polícia.

8. Nos termos da Lei n. 12.529/11, art. 11, X, compete aos conselheiros do Tribunal Administrativo de Defesa Econômica prestar informações e fornecer cópias dos autos dos procedimentos administrativos ao Poder Judiciário, quando requeridas para instruir ações judiciais, de modo que eventual sigilo do procedimento administrativo não pode ser oposto ao Poder Judiciário.

9. Recurso especial da Electrolux do Brasil S.A. prejudicado pela perda superveniente de objeto. Recurso especial de Whirlpool S.A. e Brasmotors S.A. conhecido e não provido. Prejudicada a medida cautelar vinculada ao recurso especial.

No caso, o Min. Marco Aurélio Bellizze reconheceu a importância do sigilo dos documentos que constam no procedimento administrativo do acordo de leniência para a eficiência do instituto e o sucesso das investigações.

No entanto, sustenta o Ministro que "esse princípio não pode ser absoluto e deve sempre permanecer condizente com a razão principiológica de sua existência". Em seu voto, alegou que o legislador impôs a obrigatoriedade do sigilo apenas quanto à proposta de acordo, nos termos do art. 86, $\S 9^{\circ}$ da Lei da Concorrência, estando os demais documentos constantes do procedimento administrativos sujeitos à regra geral de divulgação. Assim sendo, para que a regra de sigilo seja estendida a tais documentos, deve haver "circunstâncias concretas fundadas no interesse coletivo".

Em seu raciocínio, o Ministro Bellizze aduz que seria desproporcional a proibição de livre acesso ao público ao conteúdo do acordo de leniência, visto que tal medida configuraria verdadeiro impedimento, sem amparo legal, de terceiros prejudicados requererem a indenização pelos danos sofridos. Dessa forma, sustenta: "o sigilo do acordo de leniência não pode se protrair no tempo indefinidamente, sob pena de perpetuar o dano causado a terceiros, garantindo ao signatário do acordo de leniência favor não assegurado pela 
lei”. Não haveria, assim, qualquer óbice legal para que ação judicial seja instruída com documentos provenientes do acordo de leniência.

Por fim, o Ministro julgou que o sigilo sobre o procedimento do acordo de leniência deve perdurar até o fim da sua fase de instrução. Após, mesmo antes do julgamento do acordo pelo Tribunal Administrativo do CADE, todo o procedimento deve ser disponibilizado a quem o requeira.

Conhecendo o problema posto naquele caso $\mathrm{e}$ atento ao posicionamento jurisprudencial, o CADE editou recentemente a Resolução $n^{\circ} 21 / 2018$, na qual disciplina os procedimentos para acesso a documentos provenientes de acordos de leniência. Em que pese os problemas impostos por se tratar de uma norma regulatória sem lei prévia que defina detalhadamente o objeto e os fundamentos da regulação ${ }^{56}$, cumpre destacar importantes características da resolução.

Já no art. $1^{\circ}$, a Resolução define como públicos todos os documentos acostados ao Acordo de Leniência, listando as exceções ao princípio da publicidade no art. $2^{057}$. Ressalva, ainda, que tais exceções serão afastadas

56 "Um regulamento à espera de uma lei: resolução do Cade sobre sigilo de documentos". Daniel Caselta. 2018. Disponível em https://www.jota.info/tributos-e-empresas/concorrencia/umregulamento-a-espera-de-uma-lei-resolucao-do-cade-sobre-sigilo-de-documentos-20092018.

Acesso em 06/06/2019.

57 “Art. $2^{\circ}$ Constituem exceções ao disposto no art. $1^{\circ}$ e serão mantidos como de acesso restrito, mesmo após a decisão final pelo Plenário do Tribunal do Cade, e não poderão ser disponibilizados a terceiros:

I - o Histórico da Conduta e seus aditivos, elaborados pela Superintendência-Geral do Cade com base em documentos e informações de caráter auto-acusatório submetidos voluntariamente no âmbito da negociação de Acordo de Leniência e TCC, em razão do risco à condução de negociações (art. 23, II da Lei $\mathrm{n}^{\mathrm{o}}$ 12.527/2011), às atividades de inteligência (art. 23, VIII da Lei no 12.527/2011), e/ou à efetividade dos Programas de Leniência e de TCC do Cade; e/ou

II - os documentos e informações: a) que se enquadrem nas restrições previstas nos arts. $44, \S 2^{\circ}, 49$, $85, \S 5^{\circ}$ e $86, \S 9^{\circ}$ da Lei $n^{\circ} 12.529$, de 2011 ; b) que constituam segredo industrial (art. 22 e 23 , VIII da Lei $n^{\circ} 12.527 / 2011$ ); c) relativos à atividade empresarial de pessoas físicas ou jurídicas de direito privado cuja divulgação possa representar vantagem competitiva a outros agentes econômicos (art. $5^{\circ}, \S 2^{\circ}$ do Decreto $n^{\circ} 7.724 / 2012$ ); d) que constituam hipóteses de sigilo previstas na legislação, como fiscal, bancário, de operações e serviços no mercado de capitais, comercial, profissional, industrial e segredo de justiça (art. $6^{\circ}$, inciso I e II do Decreto $\mathrm{n}^{\mathbf{0}} 7.724 / 2012$ ); e) que constituam hipóteses previstas nos arts. 91 a 94 e 219 do Regimento Interno do Cade; f) que tenham sigilo definido por decisão judicial; g) apresentados pelo proponente durante a negociação do Acordo de Leniência ou do TCC subsequentemente frustrada, enquanto não forem restituídos aos proponentes ou destruídos pelo CADE.

$\S 1^{\circ}$ É de ônus do interessado a fundamentação das razões e a indicação do dispositivo legal que embase o caráter restrito de outros documentos e informações além daqueles elencados neste artigo. $\S 2^{\circ}$ A qualquer tempo os interessados poderão se manifestar nos autos para indicar a necessidade de manutenção do acesso restrito de documentos e informações nos termos dessa Resolução e/ou de legislação específica". 
por (i) expressa determinação legal; (ii) decisão judicial específica; ou (iii) autorização do signatário do acordo de leniência, bem como nos casos de cooperação jurídica internacional.

Ao assim dispor, a Resolução, na esteira do julgado pela Terceira Turma do STJ, reconhece a publicidade do procedimento administrativo de acordo de leniência, ainda que (i) não haja lei específica que regule o tema; e (ii) tal publicidade seja um desincentivo à celebração do acordo de leniência, como já visto.

Em seguida, a Resolução relativiza a publicidade dos documentos constantes de procedimentos que versem sobre acordos de leniência e TCC, em atenção ao risco de enfraquecimento do instituto. Na fase inicial, de negociação e celebração do acordo, todos os documentos são sigilosos. Na fase seguinte, de instrução do procedimento administrativo, são tornadas públicas as Notas Técnicas - a de instauração do procedimento e a final - da Superintendência-Geral do CADE. Por fim, o julgamento do feito administrativo pelo Plenário do Tribunal do CADE torna públicos todos os documentos e informações ainda restritos até então, a exceção daqueles listados no rol do art. $2^{\circ}$.

No entanto, por não haver regimento legal acerca do sigilo desses documentos, nada impede que estes sejam requeridos judicialmente antes de que se tornem públicos. Exemplo disso é o próprio julgado do STJ analisado: no caso, foi determinada a publicidade de todos os documentos a partir de encerrada a fase de instrução, não sendo necessário aguardar o julgamento do procedimento administrativo pelo CADE.

Portanto, ainda que louvável a intenção do CADE de estabelecer um procedimento claro e detalhado acerca da publicidade de seus procedimentos administrativos, inclusive dos feitos que versem sobre acordos de leniência, imperativo seja tomada providência legal para que a regra seja plenamente aplicável. 


\section{As Experiências nos EUAe na União Europeia}

\subsection{EUA: "Antitrust Criminal Penalty Enhancement and Reform Act" - ACPERA (2004):}

Os Estados Unidos elaboraram seu programa de leniência em 1978. Em relação à reparação civil dos danos causados pela conduta delatada, o programa norte-americano original não previa qualquer vantagem à empresa leniente: a indenização devida era regida pelo regime de punitive damages $^{58}$, com caráter solidário. Assim sendo, a responsabilidade civil do leniente poderia chegar até três vezes o dano das infrações cometidas por todos que delatou, conforme a lei estadunidense ${ }^{59}$.

Conforme reconhecido pelo Diretor Criminal da Divisão Antitruste do Departamento de Justiça dos EUA na época, o programa de leniência original implementado pelos Estados Unidos não possuía incentivos à celebração do acordo $^{60}$. Até 1993, quando o sistema de leniência foi reestruturado, o Departamento de Justiça recebeu, em média, apenas um requerimento por ano, nenhum que tenha resultada na descoberta de um cartel, crime concorrencial mais grave.

Em 1993 foi editado novo programa de leniência, tornando os critérios para aplicações e vantagens concedidas mais objetivos, sendo similar ao que

\footnotetext{
58 "Damages awarded in addition to actual damages when the defendant acted with recklessness, malice, or deceit; specif., damages assessed by way of penalizing the wrongdoer or making an example to others. Punitive damages, which are íntended to punish and thereby deter blameworthy conduct, are generally not recoverable for breach of contract. The Supreme Court has held that three guidelines help determine whether a punitive-damages award violates constitutional due process: (1) the reprehensibility ofthe conduct being punished; (2) the reasonableness ofthe relationship between the harm and the award; and (3) the difference between the award and the civil penalties authorized in comparable cases. BMW of North America, Inc. v. Gore,517 U.S. 559, 116 S.Ct. 1589 (1996). - Also termed exemplary damages; vindictive damages; punitory damages; presumptive damages; added damages; aggravated damages; speculative damages; imaginary damages" (Blacks's Law Dictionary, Bryan A. Garner, $9^{\text {th }}$ edition, West, p. 444).

${ }^{59}$ Clayton Antitrust Act, $\$ 4$, (a): "Except as provided in subsection (b), any person who shall be injured in his business or property by reason of anything forbidden in the antitrust laws may sue therefor in any district court of the United States in the district in which the defendant resides or is found or has an agent, without respect to the amount in controversy, and shall recover threefold the damages by him sustained, and the cost of suit, including a reasonable attorney's fee".

${ }_{60}$ Cornerstones of an effective leniency program. Scott D. Hammond. Disponível em https://www.justice.gov/atr/speech/cornerstones-effective-leniency-program. Acessado em 04/06/2019.
} 
está em vigor no Brasil atualmente: há previsão de imunidade criminal aos lenientes e seus diretores, bem como a possibilidade de celebração de acordo com as investigações já em curso. No mais, o sistema de leniência então adotado não previa qualquer vantagem ao delator em relação às indenizações devidas na esfera cível.

Apenas em 2004 foi promulgado o "Antitrust Criminal Penalty Enhancement and Reform Act" (ACPERA). A Lei, complementar ao programa de leniência elaborado pelo Departamento de Justiça, prevê a responsabilidade individual e limitada à extensão do dano da empresa que celebrou acordo de leniência com o Departamento de Justiça, caso os requisitos de colaboração com o Governo e com o indivíduo lesado previstos na Lei sejam alcançados.

De acordo com estudo realizado pelo United States Government Accountability Office, a pedido do Congresso norte-americano, após a entrada em vigor da ACPERA o número total de acordos celebrados entre o Departamento de Justiça e empresas lenientes não teve alterações significativas. No entanto, o número de acordos celebrados que informavam condutas ainda não investigadas pelo Estado dobrou nos cinco anos seguintes à entrada em vigor da Lei em relação aos cinco anos anteriores. Entrevistas com advogados das empresas que celebraram acordos nesse período esclareceram ao Departamento de Justiça dos EUA que a suavização da responsabilidade civil, embora importante incentivo para celebração do acordo, ainda estava atrás do risco de prisão e da sanção administrativa que a empresa e seus diretores poderiam sofrer ${ }^{61}$. Segundo a conclusão do estudo:

\footnotetext{
“After ACPERA's enactment, there was little change in the number of wrongdoers applying for leniency, an increase in successful applicants reporting previously unknown criminal conduct, and higher penalties in criminal cartel cases. Analysis of DOJ data indicate ACPERA may have resulted in little change in the number of leniency applications submitted-78 submitted in the 6 years before ACPERA versus 81 in the 6 years after - the most relevant indicator of ACPERA's impact, according to Antitrust Division officials. In addition, most defense attorneys representing leniency applicants in our sample indicated that ACPERA's offer of

${ }^{61}$ Criminal Cartel Enforcement: Stakeholder Views on Impact of 2004 Antitrust Reform Are Mixed, but Support Whistleblower Protection. United States Government Accountability Office. Disponível em https://www.gao.gov/assets/330/321794.pdf. Acesso em 04/06/2019.
} 
relief from some civil damages had a slight positive effect on leniency applicants' decisions to apply for leniency, though the threat of jail time and corporate fines were the most motivating factors both before and after ACPERA's enactment. However, after ACPERA's enactment nearly twice as many successful applicants reported criminal cartel activity about which the division had no prior knowledge. In addition, higher fines and jail times were imposed in criminal cartel cases after ACPERA's enactment, though Antitrust Division officials stated that neither trend is primarily attributable to ACPERA. Factors other than ACPERA — such as the increase of leniency programs in other countries - may also have affected the number and types of leniency applications submitted over this time period, making it difficult to isolate ACPERA's impact".

Apesar dos incentivos previstos, a ACPERA não teve os efeitos desejados em relação ao programa de leniência dos $\mathrm{EUA}^{62}$. Um dos principais motivos para a opção das empresas em não utilizarem as vantagens permitidas pela Lei de 2004 é a subjetividade dos requisitos ali previstos ${ }^{63}$. Para que sejam concedidos os benefícios, o juiz da ação de responsabilidade civil deve decidir se o leniente garantiu ao autor da demanda acesso a todas as informações e documentos potencialmente relevantes para a fundamentação de seu pleito em momento apropriado, bem como se expôs todos os fatos os quais tenha conhecimento que possam influenciar na ação e garantiu que seus diretores que cooperaram com o Departamento de Justiça estivessem disponíveis para depor sobre os fatos que envolvem a demanda e que responderam todas as perguntas de forma completa e verdadeira.

\footnotetext{
${ }^{62}$ Ressalta-se que há defensores da redação atual e dos resultados obtidos pela ACPERA. Neste sentido: ACPERA and the Value of Uncertainty. Thomas Mueller and Gregory Evans. 2010.

${ }^{63}$ Nos termos da ACPERA: "REQUIREMENTS.-Subject to subsection (c), an antitrust leniency applicant or cooperating individual satisfies the requirements of this subsection with respect to a civil action described in subsection (a) if the court in which the civil action is brought determines, after considering any appropriate pleadings from the claimant, that the applicant or cooperating individual, as the case may be, has provided satisfactory cooperation to the claimant with respect to the civil action, which cooperation shall include - (1) providing a full account to the claimant of all facts known to the applicant or cooperating individual, as the case may be, that are potentially relevant to the civil action; (2) furnishing all documents or other items potentially relevant to the civil action that are in the possession, custody, or control of the applicant or cooperating individual, as the case may be, wherever they are located; and (3)(A) in the case of a cooperating individual(i) making himself or herself available for such interviews, depositions, or testimony in connection with the civil action as the claimant may reasonably require; and (ii) responding completely and truthfully, without making any attempt either falsely to protect or falsely to implicate any person or entity, and without intentionally withholding any potentially relevant information, to all questions asked by the claimant in interviews, depositions, trials, or any other court proceedings in connection with the civil action; or (B) in the case of an antitrust leniency applicant, using its best efforts to secure and facilitate from cooperating individuals covered by the agreement the cooperation described in clauses (i) and (ii) and subparagraph (A)".
} 
Lembre-se que, ainda que todos os requisitos tenham sido cumpridos, é discricionário ao juiz decidir se irá aplicar os benefícios da Lei.

Ou seja, para que a empresa leniente não seja responsável por até três vezes a totalidade do dano causado pelo crime denunciado, ela deverá expor, na prática, toda a informação que possui sobre o crime cometido, provavelmente revelando muito mais do que gostaria em uma ação de responsabilidade civil diante de apenas um lesado, por meio escrito e em depoimentos presenciais e ainda torcer para que o juiz da causa entenda que todo seu esforço foi feito no momento apropriado e que todas as informações possíveis de serem prestadas pela empresa foram, de fato, prestadas. Caso contrário, a empresa terá comprovado as alegações do autor - e de outros eventuais autores em outras ações de responsabilidade similares - e ficará responsável pelos punitives damages em regime de indenização solidária.

Portanto, não é difícil entender porque a legislação não produziu o efeito de aumentar o número de acordos de leniência como esperado. A ACPERA, em sua forma atual, tem validade até 2020. Em 2019, o Departamento de Justiça dos EUA promove debates sobre os resultados da Lei e a possibilidade de mudanças no horizonte.

Resta, agora, expor outros aspectos legais da indenização por danos concorrenciais nos Estados Unidos.

Em primeiro lugar, consumidores indiretos ${ }^{64}$ ("indirect purchasers"), via de regra, não possuem direito a indenização dos danos sofridos, conforme posicionamento adotado pela Suprema Corte ${ }^{65}$, que demonstra a complexidade da indenização caso seja permitido a tais lesados buscarem indenização, causando grave risco da empresa ré ser responsabilizada por quantia maior que a legalmente permitida. No entanto, segundo J. Thomas

\footnotetext{
${ }^{64}$ Para ilustrar tal situação, lembre-se do exemplo dos adquirentes de carro com o motor precificado por cartel feito acima.

${ }^{65}$ Illinois Brick Co. v. Illinois, 431 U.S. 720 (1977): "Permitting the use of pass-on theories under $\S$ 4 essentially would transform treble-damages actions into massive efforts to apportion the recovery among all potential plaintiffs that could have absorbed part of the overcharge-from direct purchasers to middlemen to ultimate consumers. However appealing this attempt to allocate the overcharge might seem in theory, it would add whole new dimensions of complexity to treble-damages suits and seriously undermine their effectiveness".
} 


\title{
Rosch (ex-Comissário da Federal Trade Commission), diversos Estados
}

passaram leis que garantiam a legitimidade ativa dos consumidores indiretos em resposta ao precedente da Suprema Corte ${ }^{66}$ :

\begin{abstract}
"In response to Illinois Brick, some states have passed laws known as 'Illinois Brick repealers' that extend standing to indirect purchasers, including consumers. Such laws have had the effect, of course, of subjecting an antitrust defendant to liability from multiple lawsuits by direct purchasers and indirect purchasers and duplicative recoveries - just as the Supreme Court had feared. An antitrust defendant's exposure thus has sometimes far exceeded the treble-damages, which can put tremendous pressure on the defendant to settle a case regardless of its merit, and can lead to extortionate settlements".
\end{abstract}

No mais, por força da subseção (b)(7) do Freedom of Information $A c t^{67}$, os documentos que constam do acordo de leniência não são tornados públicos às partes da demanda judicial.

Por fim, cumpre ressaltar que o prazo prescricional para a ação de indenização nos EUA é de quatro anos, contados a partir da efetivação do dano $^{68}$.

\subsection{Europa: "Diretiva sobre Ações de Ressarcimento de Danos Concorrenciais na União Europeia" (2014):}

\footnotetext{
${ }^{66}$ Designing a Private Remedies System for Antitrust Cases - Lessons Learned from the U.S. Experience. J. Thomas Rosch. 2011. Disponível em: https://www.ftc.gov/sites/default/files/documents/public_statements/designing-private-remediessystem-antitrust-cases-lessons-learned-u.s.experience/110617roschprivateremedies.pdf. Acessado em 05/06/2019.

67 “'(b) This section does not apply to matters that are - (...) (7) records or information compiled for law enforcement purposes, but only to the extent that the production of such law enforcement records or information (A) could reasonably be expected to interfere with enforcement proceedings, (B) would deprive a person of a right to a fair trial or an impartial adjudication, (C) could reasonably be expected to constitute an unwarranted invasion of personal privacy, (D) could reasonably be expected to disclose the identity of a confidential source, including a State, local, or foreign agency or authority or any private institution which furnished information on a confidential basis, and, in the case of a record or information compiled by a criminal law enforcement authority in the course of a criminal investigation or by an agency conducting a lawful national security intelligence investigation, information furnished by a confidential source, (E) would disclose techniques and procedures for law enforcement investigations or prosecutions, or would disclose guidelines for law enforcement investigations or prosecutions if such disclosure could reasonably be expected to risk circumvention of the law, or $(\mathrm{F})$ could reasonably be expected to endanger the life or physical safety of any individual".

${ }^{68}$ Daniel Costa Caselta. Responsabilidade civil por danos decorrentes da prática de cartel. USP (Mestrado), 2015, p. 71.
} 
Em 2014 o Parlamento da União Europeia editou a "Diretiva sobre Ações de Ressarcimento de Danos Concorrenciais na União Europeia" (Diretiva), que tem por objetivo regular a ação de indenização decorrente de danos concorrenciais sob a jurisdição da União Europeia.

Em primeiro lugar, interessante destacar trecho da exposição de motivos da Diretiva, que reflete os posicionamentos opostos do sistema de incentivos ao acordo de leniência e da responsabilidade civil do leniente do dano concorrencial e a necessidade de equilíbrio, já exposto nos capítulos anteriores: "Para assegurar a efetiva aplicação privada no âmbito do direito civil e a efetiva aplicação pública pelas autoridades da concorrência, ambos os instrumentos são necessários para interagir de forma a assegurar a máxima eficácia das regras da concorrência”.

Assim como no direito brasileiro, a Diretiva garante a reparação integral do dano e nada além disso ${ }^{69}$, não prevendo o instituto do punitive damages.

$\mathrm{O}$ art. 12 da Diretiva garante também ao consumidor indireto o direito à indenização integral dos danos que tenha sofrido, sendo de responsabilidade dos Estados membros aplicar medidas processuais que visem garantir que a indenização realizada não supere os danos sofridos por determinado nível da "cadeia de abastecimento".

A Diretiva prevê que o início da contagem do prazo prescricional, de no mínimo cinco anos, se dará (i) após cessada a infração; e (ii) a partir do momento em que se possa "razoavelmente presumir" que o autor tenha conhecimento da infração concorrencial que tenha lhe causado danos e da identidade do infrator ${ }^{70}$. Inteligentemente, o prazo prescricional restará

\footnotetext{
69 “Artigo $3^{\circ}$ Direito à reparação integral:

1. Os Estados-Membros asseguram que as pessoas singulares ou coletivas que sofram danos causados por infrações ao direito da concorrência possam pedir e obter a reparação integral desses danos.

2. A reparação integral coloca a pessoa que sofreu danos na posição em que estaria se a infração ao direito da concorrência não tivesse sido cometida. Por conseguinte, abrange o direito à reparação por danos emergentes e por lucros cessantes acrescido do pagamento de juros.

3. A reparação integral nos termos da presente diretiva não pode conduzir à reparação excessiva, por meio de indemnizações punitivas, múltiplas ou de outro tipo".

${ }^{70}$ Diretiva sobre Ações de Ressarcimento de Danos Concorrenciais na União Europeia, art. 10 (2).
} 
suspenso ou interrompido caso a autoridade concorrencial do país membro esteja investigando a conduta ilícita até, ao menos, um ano após prolação da decisão do mérito da infração ou do término da investigação de outra forma ${ }^{71}$.

Ademais, a Diretiva determina a responsabilização solidária em caso de infração concorrencial conjunta por todos os danos causados, permitindo o direito de regresso, por quem arcou com parte maior que a que efetivamente lhe caberia, contra as demais. Como incentivo à celebração do acordo de leniência, a Diretiva exclui a responsabilidade solidária da empresa leniente, ficando ela obrigada ao ressarcimento somente do dano que efetivamente tenha causado, direto e indireto.

Como se vê, o sistema de responsabilidade civil concorrencial do direito europeu é puramente objetivo, não deixando qualquer margem à interpretação do magistrado, diferentemente do direito americano.

Por fim, cumpre ressaltar importante inovação da Diretiva na ação de responsabilidade civil por dano concorrencial: a criação de níveis de sigilo de documentos. Para melhor entendimento, importante que se faça um breve histórico dos fatos que motivaram a União Europeia a editar a Diretiva com tal regra.

Em 2008, foi celebrado acordo de leniência entre a Bundeskartellamt (autoridade de concorrência alemã) e empresa do setor de fabricação de papel decorativo acerca da prática de cartel naquele mercado, que resultou na aplicação de diversas penas às empresas cartelizadas. Em seguida, a companhia Pfleiderer, consumidora dos produtos cartelizados, requereu acesso aos documentos obtidos e apurados pela autoridade de concorrência alemã, para instruir sua ação de reparação civil ${ }^{72}$.

\footnotetext{
${ }^{71}$ Diretiva sobre Ações de Ressarcimento de Danos Concorrenciais na União Europeia, art. 10 (4): "Os Estados-Membros asseguram que o prazo de prescrição seja suspenso ou, consoante o direito nacional, interrompido, se a autoridade da concorrência tomar medidas no âmbito de uma investigação ou de um processo relativo a uma infração ao direito da concorrência com a qual a ação de indemnização esteja relacionada. A suspensão termina, no mínimo, um ano depois de a decisão em matéria de infração se ter tornado definitiva ou depois de o processo ter sido de outro modo concluído".

72 Tribunal de Justiça da União Europeia (Grande Secção), Acórdão de 14 de junho de 2011, Pfleiderer AG contra Bundeskartellamt, C-360/09, ECLI:EU:C:2011:389.
} 
Esse pleito de obtenção de documentos foi a julgamento na Corte de Justiça da União Europeia, que firmou o seguinte entendimento ${ }^{73}$ :

\begin{abstract}
"Tendo em conta as considerações precedentes, há que responder à questão submetida que as disposições do direito da União em matéria de cartéis, em especial o Regulamento $\mathrm{n}^{\circ} 1 / 2003$, devem ser interpretadas no sentido de que não se opõem a que uma pessoa lesada por uma infracção ao direito da concorrência da União e que procura obter uma indemnização tenha acesso aos documentos relativos a um procedimento de clemência respeitante ao autor da referida infracção. Incumbe, porém, aos órgãos jurisdicionais dos Estados-Membros, com base no seu direito nacional, determinar as condições nas quais tal acesso deve ser autorizado ou recusado, através da ponderação dos interesses protegidos pelo direito da União".
\end{abstract}

Segundo a decisão proferida pela Corte, seria competência de cada Estado regular a disponibilização de documentos constantes de acordo de leniência.

Diante da insegurança jurídica causada pela decisão da Corte e do caráter muitas vezes internacional das infrações concorrenciais cometidas dentro do Mercado Comum Europeu, o Parlamento Europeu buscou retificar o posicionamento anteriormente adotado por meio da Diretiva.

O Capítulo II da Diretiva dispõe sobre a "Divulgação de Elementos de Prova" para instrução das ações de responsabilidade civil.

Estabelece, primeiramente, a possibilidade do requerimento judicial de juntada de documentos que comprovem a infração concorrencial a terceiros, ressalvando, inicialmente, que tal pedido deve atentar à proporcionalidade, devendo haver um contexto fático e jurídico que garantam indícios do direito do autor e não ser possível sua obtenção exclusivamente pelo demandante, bem como serem ponderados os gastos de recursos pelo terceiro para prover tais documentos à corte e a confidencialidade dos documentos, especialmente em relação a informações de terceiros ${ }^{74}$. Ademais, o pedido deve ser formulado de forma específica.

\footnotetext{
73 Tribunal de Justiça da União Europeia (Grande Secção), Acórdão de 14 de junho de 2011, Pfleiderer AG contra Bundeskartellamt, C-360/09, ECLI:EU:C:2011:389, item 32.

${ }^{74}$ Diretiva sobre Ações de Ressarcimento de Danos Concorrenciais na União Europeia, art. $5^{\circ}$.
} 
Em seguida, a Diretiva observa exceção a tal regra: os procedimentos administrativos ainda em curso pela autoridade concorrencial competente de cada país. Nestes casos, qualquer documento elaborado especificamente para instrução do procedimento administrativo, pelas partes, pela autoridade ou por terceiros e as propostas de transação revogadas poderão ser requisitadas pelas cortes nacionais somente após o julgamento do caso administrativo.

Por fim, a Diretiva prevê dois tipos de documentos que não podem ser juntados em qualquer hipótese em ação de responsabilidade civil por dano concorrencial: as declarações de clemência (leia-se leniência) e as propostas de transação. Tais documentos não podem ser requeridos pelos tribunais nacionais e, caso acostados aos autos, devem ser considerados provas inadmissíveis. Tal norma tem fundamento em garantir o incentivo às empresas infratoras em confessar as práticas ilícitas. Segundo a exposição de motivos da Diretiva:

\footnotetext{
"Os programas de clemência e os procedimentos de transação são ferramentas importantes para a aplicação pública do direito da concorrência da União, uma vez que contribuem para a deteção e investigação eficiente das infrações mais graves ao direito da concorrência, e para a imposição de sanções contra tais infrações. Além disso, como muitas decisões das autoridades da concorrência em processos de cartéis se baseiam numa declaração de clemência e as ações de indemnização nos processos de cartéis decorrem, de um modo geral dessas decisões, os programas de clemência são igualmente importantes para a efetividade de ações de indemnização em processos de cartéis. As empresas poderão ser dissuadidas de cooperar com as autoridades da concorrência no âmbito de programas de clemência e procedimentos de transação, se forem divulgadas declarações autoincriminatórias, como sejam declarações de clemência e propostas de transação produzidas unicamente para efeitos dessa cooperação com as autoridades da concorrência. Tal divulgação implicaria o risco de expor as empresas cooperantes ou o seu pessoal de gestão à responsabilidade civil ou penal em condições mais desfavoráveis do que os coinfratores que não cooperam com as autoridades da concorrência. Para assegurar que as empresas continuem dispostas a apresentar voluntariamente às autoridades da concorrência declarações de clemência ou propostas de transação, esses documentos deverão ser excluídos da divulgação de elementos de prova. Tal isenção deverá aplicar-se também às citações literais de uma declaração de clemência ou de uma proposta de transação incluídas noutros documentos. Essas limitações em matéria de divulgação de elementos de prova não deverão impedir as autoridades da concorrência de publicarem as suas decisões em conformidade com o direito da União ou nacional aplicável. A fim de assegurar que esta isenção relativamente à divulgação não afete indevidamente o direito dos lesados à reparação, esta deverá limitar-se a tais declarações de clemência e propostas de transação voluntárias e autoincriminatórias".
} 
Em suma, a Diretiva se preocupou em dividir os documentos que possam instruir ações de indenização fundadas em dano concorrencial em três grupos: (i) os documentos permitidos; (ii) os documentos que só serão permitidos após julgamento do procedimento administrativo pela autoridade competente; e (iii) os documentos vedados.

Todas as regras previstas na Diretiva visam a garantir a existência de regras claras e objetivas que definam o procedimento e o direito do demandante, no sentido contrário das ações similares que tramitam sob a jurisdição norte-americana. 


\section{Previsão de Nova Regulação no Brasil: O Projeto de Lei $n^{\circ}$ 11.275/2018 e uma Sugestão aos Legisladores}

Atualmente, tramita na Câmara dos Deputados o projeto de lei $n^{\circ}$ 11.275/2018 (originalmente o projeto de lei $\mathrm{n}^{\mathrm{o}}$ 283/2016 do Senado Federal) de autoria do então Senador Aécio Neves, proposto em 06/07/2016. O projeto foi aprovado no Plenário do Senado Federal no fim de 2018 e atualmente se encontra na Comissão de Desenvolvimento Econômico, Indústria, Comércio e Serviços da Câmara dos Deputados.

O objetivo da proposta do legislativo é incentivar a busca pelos lesados da reparação dos danos que sofreram em virtude do ilícito concorrencial, estimular também a celebração de acordos de leniência. Neste ponto, o projeto altera a Lei da Concorrência para garantir ao lesado prazo prescricional de cinco anos para ajuizamento da demanda indenizatória, contado a partir da "ciência inequívoca do ilícito" e que restará suspenso durante o procedimento administrativo no âmbito do CADE.

Ademais, o projeto prevê o ressarcimento em dobro aos prejudicados dos danos concorrenciais previstos no art. 47 da Lei de Concorrência ${ }^{75}$.

No âmbito do processo judicial, o projeto busca interessante inclusão no ordenamento jurídico: a decisão que reconhece a existência de infração econômica pelo Plenário do CADE será apta a fundamentar decisão de concessão liminar de tutela de evidência ${ }^{76}$ na demanda judicial indenizatória.

\footnotetext{
75 “Art. 47. Os prejudicados, por si ou pelos legitimados referidos no art. 82 da Lei no 8.078 , de 11 de setembro de 1990, poderão ingressar em juízo para, em defesa de seus interesses individuais ou individuais homogêneos, obter a cessação de práticas que constituam infração da ordem econômica, bem como o recebimento de indenização por perdas e danos sofridos, independentemente do inquérito ou processo administrativo, que não será suspenso em virtude do ajuizamento de ação".

76 "Art. 311. A tutela da evidência será concedida, independentemente da demonstração de perigo de dano ou de risco ao resultado útil do processo, quando:

I - ficar caracterizado o abuso do direito de defesa ou o manifesto propósito protelatório da parte;

II - as alegações de fato puderem ser comprovadas apenas documentalmente e houver tese firmada em julgamento de casos repetitivos ou em súmula vinculante;

III - se tratar de pedido reipersecutório fundado em prova documental adequada do contrato de depósito, caso em que será decretada a ordem de entrega do objeto custodiado, sob cominação de multa;

IV - a petição inicial for instruída com prova documental suficiente dos fatos constitutivos do direito do autor, a que o réu não oponha prova capaz de gerar dúvida razoável.

Parágrafo único. Nas hipóteses dos incisos II e III, o juiz poderá decidir liminarmente".
} 
Isso significa que, em caso de reconhecimento do ilícito concorrencial pelo CADE, o juiz da ação de responsabilidade civil concorrencial poderá determinar o ressarcimento de forma liminar, sem que haja qualquer demonstração de perigo na demora da concessão da tutela estatal. Dessa forma, o prejudicado não teria que esperar o trânsito em julgado da lide para reaver seus prejuízos. Por óbvio, o autor da demanda deverá, para que seja concedida a medida, expor detalhadamente e comprovar os danos que alega terem sido sofridos e, caso seja revertida a liminar em sede de sentença, retornar a quantia, atualizada, ao réu.

Por fim, quanto ao celebrante de acordo de leniência com o CADE, o projeto prevê isenção de sua responsabilidade solidária. Além disso, caso o leniente acoste no procedimento administrativo "documentos que permitam ao CADE a estimação do dano decorrente da infração à ordem econômica", será concedido também o benefício de isenção de responsabilidade quanto ao ressarcimento em dobro. Assim sendo, o signatário do acordo seria responsável somente pela restituição simples do dano que sua conduta tenha causado.

O projeto do hoje Deputado Aécio Neves tem clara inspiração na ACPERA, norma dos Estados Unidos, ainda que preveja critérios mais objetivos para concessão dos benefícios ali previstos.

Importante, nesse momento, tecer breves críticas ao projeto legislativo.

Ao determinar que o prazo prescricional comece a ser contado a partir da ciência do ilícito, e não da ciência do dano, o projeto confere à legislação caráter mais restritivo do que a interpretação atual do Superior Tribunal de Justiça sobre o tema, já explorada nos capítulos anteriores. Isso porque é possível ao lesado ter ciência do ato ilícito sem que haja ciência do dano. Basta imaginar, conforme exemplo exposto acima, que o comprador de um carro tenha ciência de ilícito concorrencial cometido por fabricante de motores, mas não saiba que tal empresa tenha produzido o motor do seu carro e que, portanto, é seu consumidor indireto. 
Ademais, o projeto insere a figura do punitive damages na responsabilidade civil, o que difere diretamente do art. 944 do Código Civil ${ }^{77}$ e funcionaria como exceção perigosa ao princípio da reparação integral do dano. Isso porque não há qualquer parâmetro que defina o modo ou o valor de sua aplicação no ordenamento jurídico brasileiro. Em qualquer caso a empresa deverá ser condenada ao valor dobrado do dano causado? Poderia o juiz diminuir o multiplicador no caso? Se a empresa celebrar acordo de leniência plus, ela ainda estaria sujeita aos punitive damages? São questões fundamentais para a implementação do instituto que o projeto, por si, falha em responder, não garantindo a segurança e a previsibilidade necessárias às empresas que estudam a possibilidade de celebrar acordo.

Por fim, cumpre ressaltar que o projeto, em seu estado atual, não resolve a questão da produção de prova na demanda de responsabilidade civil. Não há qualquer regulação acerca da admissibilidade do procedimento administrativo no âmbito do CADE como meio de prova da demanda de reparação civil, o que reforça a insegurança da empresa no momento de avaliação se vale a pena buscar o acordo de leniência junto a autarquia.

Importante ressaltar que é imperativa nova solução legal para o problema apresentado neste trabalho. Conforme exposto pelo CADE na exposição de motivos para a edição da Resolução nº 21/2018:

"O Programa de Leniência do Conselho Administrativo de Defesa Econômica (Cade), assim como verificado na experiência internacional, é uma das principais ferramentas no combate a cartéis. O Termo de Compromisso de Cessação (TCC), em especial após 2013, também se consolidou, no Brasil, como importante ferramenta complementar à repressão de condutas anticompetitivas, semelhantemente ao que se constata nas melhores práticas estrangeiras. Essas duas ferramentas - Acordo de Leniência e TCC - consubstanciam pilares da persecução pública a condutas anticompetitivas no Brasil ("public enforcement"). De modo contundente no exterior e incidental no Brasil, verifica-se a crescente persecução privada a tais condutas anticompetitivas, por meio do ajuizamento de ACRDC ("private enforcement").

Essa articulação entre persecução pública e privada a condutas anticompetitivas, portanto, torna-se imperiosa, tendo sido objeto de recentes discussões em fóruns internacionais. Por um lado, regras que favoreçam excessivamente private enforcement podem prejudicar o public enforcement. Por outro lado, regras que sejam excessivamente restritivas podem inviabilizar o ressarcimento da parte

\footnotetext{
77 “Art. 944. A indenização mede-se pela extensão do dano”.
} 
lesada pela infração à ordem econômica e inviabilizar parte significativa do enforcement antitruste. É dado o momento de o Brasil finalmente se posicionar institucionalmente a respeito do tema".

No entanto, pelos pontos acima expostos, resta claro que a instituição de um programa de leniência efetivo passa por alteração legal diversa daquela atualmente em trâmite no Congresso.

$\mathrm{Na}$ verdade, o melhor método para equilibrar as questões conflitantes de incentivo ao instituto do acordo de leniência e possibilitar a reparação integral do dano causado é impedir que as demandas de reparação pelos lesados cheguem ao judiciário, tendo um fim célere e que satisfaça ambos os polos. Dessa forma, sugere-se ao legislador a seguinte resposta ao problema exposto:

Em primeiro lugar, imperativo que o Ministério Público negocie o ressarcimento também do dano que gera responsabilidade civil causado pela conduta anticoncorrencial no momento de negociação do acordo de leniência. A partir de documentos e estudos que permitam a quantificação dos danos a terceiros causados pelo ato ilícito, o acordo deverá incluir também a indenização no valor calculado.

Antes de celebrar o acordo, o parquet abriria edital amplamente publicizado, inclusive pela empresa leniente, por alguns meses, para que as pessoas tenham conhecimento do dano e possam se alistar como detentores de direito contra aquela empresa. O acordo poderia ser celebrado somente após o fim deste período de inscrição, para que os danos que os inscritos alegam sofrer sejam considerados na negociação. Após o cumprimento do acordo com o pagamento da indenização, o Ministério Público deverá (i) criar um fundo para aplicação da quantia ${ }^{78}$; e (ii) analisar os comprovantes dos danos sofridos e, então, repassar a indenização às pessoas lesadas. $\mathrm{O}$

\footnotetext{
${ }^{78}$ Cumpre ressaltar, neste ponto, que não se entende imperativo que o parquet seja o gestor desse fundo. Com efeito, diante das extensas atribuições do Ministério Público, seria mais efetivo a criação de um órgão específico, vinculado ao CADE ou à própria procuradoria, signatários do acordo, para que faça a gestão do dinheiro, análise dos danos alegados e repasse aos indivíduos lesados.
} 
procedimento, neste último passo, será idêntico ao previsto para reparação de danos individuais reparados em sede de ação civil pública ${ }^{79}$.

O fundo terá a validade do prazo prescricional da demanda. Ele deverá ressarcir primeiramente as pessoas que se inscreveram no edital ${ }^{80} \mathrm{e}$, em seguida, requerimentos posteriores. Após, a quantia não retirada será revertida em favor da sociedade, com finalidade a ser dada pelo legislador ${ }^{81}$.

Caso o fundo se esgote sem que todos os lesados tenham sido reparados pelo dano sofrido, o acordo de leniência funcionará como título extrajudicial que poderá ser executado pelas pessoas que ainda não tenham sido ressarcidas.

Tal proposta garantirá previsibilidade a empresa, que deverá ressarcir todos os danos causados após a celebração do acordo, e celeridade às demandas individuais de reparação civil, de modo que o prejudicado poderá rapidamente ser ressarcido de seu dano.

Por óbvio, para que essa proposta seja efetiva, a solidariedade em relação a empresa leniente deverá ser extinta, nos mesmos termos do projeto de lei apresentado pelo então Senador Aécio Neves.

Do mesmo modo, o prazo prescricional de cinco anos proposto é razoável ao garantir longo período para a demanda de reparação civil.

Além disso, deverão ser incluídas na nova lei as sugestões já apresentadas acima, como a interrupção do prazo prescricional durante o

\footnotetext{
${ }^{79}$ Lei $\mathrm{n}^{\circ}$ 7.347/85 (Lei da Ação Civil Pública): “Art. 13. Havendo condenação em dinheiro, a indenização pelo dano causado reverterá a um fundo gerido por um Conselho Federal ou por Conselhos Estaduais de que participarão necessariamente o Ministério Público e representantes da comunidade, sendo seus recursos destinados à reconstituição dos bens lesados.

$\S 1^{\circ}$. Enquanto o fundo não for regulamentado, o dinheiro ficará depositado em estabelecimento oficial de crédito, em conta com correção monetária.

$\S 2^{\circ}$. Havendo acordo ou condenação com fundamento em dano causado por ato de discriminação étnica nos termos do disposto no art. 1o desta Lei, a prestação em dinheiro reverterá diretamente ao fundo de que trata o caput e será utilizada para ações de promoção da igualdade étnica, conforme definição do Conselho Nacional de Promoção da Igualdade Racial, na hipótese de extensão nacional, ou dos Conselhos de Promoção de Igualdade Racial estaduais ou locais, nas hipóteses de danos com extensão regional ou local, respectivamente".

${ }^{80}$ Tendo em vista que tais demandas seriam computadas na negociação do acordo, o Ministério Público não poderia aceitar indenização em valor menor ao da soma dos requerimentos dos inscritos no edital.

${ }^{81}$ Uma sugestão possível ao legislador seria a destinação da quantia não retirada do fundo para um fim social dentro do setor de atuação da empresa leniente. Por exemplo: caso a empresa atue no setor de saúde, o fundo seria convertido em medidas sociais na área de saúde.
} 
trâmite do procedimento administrativo e o início de sua contagem a partir do conhecimento do dano, não do ato ilícito.

No entanto, caso essa opção de extrajudialização das demandas de reparação dos danos concorrenciais das empresas celebrantes de acordo de leniência não seja adotada, importante que sejam garantidas instruções legais mais claras quanto a tais demandas.

Seria prudente, neste ponto, importar o modelo europeu, em especial no que versa sobre a produção de prova na lide, visto que este é facilmente moldável ao direito brasileiro, não havendo qualquer incompatibilidade, e que se mostrou uma política eficiente e prática para garantir o equilíbrio entre os incentivos para celebração do acordo de leniência e o ressarcimento integral do dano.

Além disso, seria interessante manter a disposição atual do projeto no que tange a concessão de tutela de evidência, de modo a garantir a efetividade da tutela jurisdicional de forma mais célere ao demandante.

No mais, quanto aos legítimos para propositura da demanda, não há motivos para alterar a previsão legal do art. 47 da Lei de Concorrência, visto que esta, como já exposto, faz boa definição de ambos os polos. 


\section{Conclusão}

Historicamente, o acordo de leniência se apresenta como o principal instituto no combate a crimes concorrenciais, tendo em vista a dificuldade de provar as condutas criminosas praticadas. Assim sendo, imperativo que o programa de leniência brasileiro seja forte e tenha incentivos suficientes às empresas a fim de que entendam vantajoso celebrar o acordo.

No entanto, não é o que ocorre. Atualmente, o programa de leniência brasileiro não possui incentivos suficientes para que as empresas tenham o interesse em celebrar acordo sem que haja investigação prévia, conforme demonstrado pela Operação Lava Jato.

Dessa forma, é imperativa a realização de alterações significativas no programa de leniência brasileiro. No entanto, importante que essa reforma não proteja demais os lenientes em detrimento das pessoas que foram lesadas pela conduta ilícita.

Conforme demonstrado, o direito à reparação civil do dano concorrencial é elemento inafastável do ordenamento jurídico, não podendo haver restrições ao direito do lesado de ser ressarcido pelos danos que tenha sofrido pela conduta ilícita, seja agente econômico celebrante do acordo de leniência, seja de outra empresa denunciada no acordo. Nenhum dos países estudados prevê qualquer limite ao princípio da reparação integral do dano.

Assim sendo, importante que o programa de leniência a ser instituído preveja outros benefícios, a serem concedidos de forma objetiva, ao confessante: previsibilidade quanto a quantia a ser indenizada - tanto no âmbito administrativo quanto no cível -, extinção da solidariedade e proteção a informações sensíveis, por exemplo. Tais benefícios buscam atrair as pessoas que cometem infrações concorrenciais a celebrarem o acordo sem, no entanto, impedir o ressarcimento total dos prejudicados.

Apesar de atualmente estar tramitando no Congresso projeto de Lei que verse sobre o assunto, tal projeto falha em proteger qualquer um dos interesses em conflito. $\mathrm{O}$ confessante não teria segurança quanto aos 
documentos acostados no procedimento administrativo nem em relação a previsibilidade do valor a ser pago e contra o prejudicado correria um prazo prescricional mais restritivo - ainda que maior -, do que a norma atual.

Dessa forma, imperativo que seja proposta nova mudança. Permitir ao Ministério Público negociar, no âmbito do próprio acordo de leniência, a reparação civil devida e determinar que os lesados pela conduta ilícita busquem sua indenização através do fundo a ser criado, nos moldes já previstos em lei no caso de ação civil pública, seria um importante passo para fortalecer o programa de leniência brasileiro. 


\section{BIBLIOGRAFIA:}

$5^{\text {a }}$ CÂMARA DE COORDENAÇÃO E REVISÃO DO MINISTÉRIO PÚBLICO FEDERAL. Estudo Técnico nº 01/2017. - Combate à Corrupção. Disponível em https://bit.ly/2JxMQdG;

CADE, processo administrativo $\mathrm{n}^{\circ}$ 08012.009888/2003-70, Conselheiro Relator Fernando de Magalhães Furlan, julgado em 01/09/2010;

CASELTA, Daniel. Um regulamento à espera de uma lei: resolução do Cade sobre sigilo de documentos. 2018. Disponível em https://www.jota.info/tributos-e-empresas/concorrencia/um-regulamento-aespera-de-uma-lei-resolucao-do-cade-sobre-sigilo-de-documentos20092018;

CASELTA. Daniel Costa. Responsabilidade civil por danos decorrentes da prática de cartel. USP (Mestrado), 2015;

CONNOR, John "Information on settlement amounts is available for a large majority of the cartels, but several are still being negotiated. In the United States, private parties recovered at least $\$ 19.7$ billion from defendants in international cartels". 2008. Global Antitrust Prosecutions of International Cartels: Focus on Asia. SSRN Electronic Journal;

DIREITO, Carlos Alberto Menezes e FILHO, Sergio Cavalieri. Comentários ao Novo Código Civil: Da responsabilidade civil, das preferências e privilégios creditórios. Arts. 927 a 965. Vol. XIII. Coord. Sálvio de Figueiredo Teixeira. Rio de Janeiro: Forense, 2011, $3^{\mathrm{a}}$ edição; 
FERRAZ JÚNIOR, Tércio Sampaio. Direito da Concorrência e Enforcement Privado na Legislação Brasileira. In Revista de Defesa da Concorrência, v. I, $\mathrm{n}^{\mathrm{o}} 2$, novembro de 2013;

FILHO, Sergio Cavalieri. Programa de Responsabilidade Civil. São Paulo: Malheiros, $6^{\text {a }}$ edição, 2006;

GARNER, Bryan A., Blacks's Law Dictionary, $9^{\text {th }}$ edition, West;

HAMMOND, Scott D. Cornerstones of an effective leniency program. Disponível em https://www.justice.gov/atr/speech/cornerstones-effectiveleniency-program

JUCÁ, Paulo Renato. A reparação civil no crime de cartel nas hipóteses de acordo de leniência com o CADE. 2019. No prelo.

JUNIOR, Humberto Theodoro. Comentários ao Novo Código Civil: Dos atos jurídicos lícitos. Dos atos ilícitos. Da prescrição e da decadência. Da prova. Arts. 185 a 232. Vol. III, Tomo II. Coord. Sálvio de Figueiredo Teixeira. Rio de Janeiro: Forense, 2008;

MAGGI, Bruno Oliveira. Cartel: Reponsabilidade Civil Concorrencial. São Paulo: Thomson Reuters, 2018;

MAGGI, Bruno Oliveira. O cartel e seus efeitos na responsabilidade civil. USP (Mestrado), 2010;

MARTINS, Frederico Bastos Pinheiro. Obstáculos às ações privadas de reparação de danos decorrentes de cartéis. FGV (Mestrado). 2017, p. 25; 
MINISTÉRIO DA JUSTIÇA. Guia Programa de Leniência Antitruste do Cade. Setembro de 2017;

MUELLER, Thomas and EVANS, Gregory. ACPERA and the Value of Uncertainty. 2010;

PEREIRA, Caio Mário da Silva. Responsabilidade Civil. Rio de Janeiro: Forense. 2016. $11^{\mathrm{a}}$ edição;

ROSCH, J. Thomas. Designing a Private Remedies System for Antitrust Cases - Lessons Learned from the U.S. Experience. 2011;

SCHREIBER, Anderson et al. Código Civil Comentado: Doutrina e Jurisprudência. Rio de Janeiro: Forense, 2019;

SOUZA. Nayara Mendonça da Silva. Mecanismos de Proteção ao Programa de Leniência Brasileiro. Revista do IBRAC - Direito da Concorrência, Consumo e Comércio Europeu, vol. 26, 2014, p. 115/134.

STJ, REsp 1.180.237, Rel. Min. Paulo de Tarso Sanseverino, Terceira Turma, j. 19.06.12;

STJ, REsp 1.354.348, rel. Min. Luis Felipe Salomão, Quarta Turma, j. 26.08.14;

STJ, REsp 1.554.986, Rel. Min. Marco Aurélio Bellizze, Terceira Turma, j. 08.03.19;

TEPEDINO, Gustavo, BARBOSA, Heloiza Helena e DE MORAES, Maria Celina Bodin. Código Civil Interpretado de Acordo com a Constituição da 
República. Vol. I, Parte Geral e Obrigações (arts. $1^{\circ}$ a 420). Rio de Janeiro: Renovar, 2004;

TRIBUNAL DE JUSTIÇA DA UNIÃO EUROPEIA (Grande Secção), Acórdão de 14 de junho de 2011, Pfleiderer AG contra Bundeskartellamt, C360/09, ECLI:EU:C:2011:389; e

UNITED STATES DEPARTMENT OF JUSTICE. The Modern Leniency Program After Ten Years - A Summary Overview of the Antitrust Division's Criminal Enforcement Program. 2003;

UNITED STATES GOVERNMENT ACCOUNTABILITY OFFICE. Criminal Cartel Enforcement: Stakeholder Views on Impact of 2004 Antitrust Reform Are Mixed, but Support Whistleblower Protection. Disponível em https://www.gao.gov/assets/330/321794.pdf;

UNITED STATES SUPREME COURT, Illinois Brick Co. v. Illinois, 431 U.S. 720 (1977). 